\title{
TRABALHO DECENTE SEGUNDO A OIT: UMA CONCEPÇÃO DEMOCRÁTICA? ANÁLISE CRÍTICA À LUZ DA TEORIA DO CONTRATO SOCIAL
}

\author{
DECENT WORK ACCORDING TO THE ILO: A DEMOCRATIC CONCEPTION? \\ CRITICAL ANALYSIS AS CLAIMED BY THE SOCIAL CONTRACT THEORY
}

\section{TRABAJO DECENTE SEGÚN LA OIT: UNA CONCEPCIÓN DEMOCRÁTICA? ANÁLISIS CRÍTICA A VISTA DE LA TEORIA DEL CONTRATO SOCIAL}

\author{
Silvio Beltramelli Neto \\ https://orcid.org/0000-0002-3940-5983 / http://lattes.cnpq.br/4777371367391173 / silviobeltramelli@gmail.com \\ Pontifícia Universidade Católica de Campinas, PUC-Campinas.
} Campinas, SP, Brasil

ISADORA REZENDE BONAMIM https://orcid.org/0000-0002-1820-1295 / http://lattes.cnpq.br/0906219095787467 /isabonamim@gmail.com Pontifícia Universidade Católica de Campinas, PUC-Campinas. Campinas, SP, Brasil

JULIA DE CARVALho VoltanI https://orcid.org/0000-0002-0278-8490 / http://lattes.cnpq.br/8515432545652391 / juliavoltani@gmail.com Pontifícia Universidade Católica de Campinas, PUC-Campinas.

\begin{abstract}
RESUMO
A partir da teoria do Contrato Social de Jean-Jacques Rousseau e da percepção de Boaventura de Sousa Santos acerca da hodierna crise desse Contrato, o artigo discute a natureza democrática da adoção pela OIT da concepção de Trabalho Decente, pondo em causa o tripartismo e o diálogo social aplicados tanto na escala internacional, quando da eleição do Trabalho Decente como diretriz das ações da OIT, quanto na escala estatal, por ocasião da elaboração da Agenda Nacional do Trabalho Decente brasileira. Conclui-se que as concepções de Trabalho Decente e da Agenda Nacional de Trabalho Decente brasileira, a despeito de não serem antidemocráticas, também não podem ser tomadas como suficientemente democráticas, ante a crise do Contrato Social, que afeta, de forma direta, os pilares da democracia representativa e da função socialmente inclusiva do trabalho, com a consequente fragilização da representatividade das entidades sindicais e do papel Estado enquanto agente normalizador das desigualdes sociais. Empregaram-se o método de abordagem hipotético-dedutivo e os métodos de procedimento histórico e bibliográfico.
\end{abstract}

Palavras-chave: Agenda Nacional do Trabalho Decente; Contrato Social; Cooperação Internacional; Democracia; Trabalho Decente.

\section{ABSTRACT}

Based on Jean-Jacques Rousseau's Theory of Social Contract and Boaventura de Sousa Santos's perception of the current crisis of this Contract, the article discusses the democratic nature of the ILO's adoption of the Decent Work concept, the tripartism and the social dialogue applied at the international level, when the Decent Work was elected 2017/15639-8. 
ISSN 1981-3694

(DOI): 10.5902/1981369433853

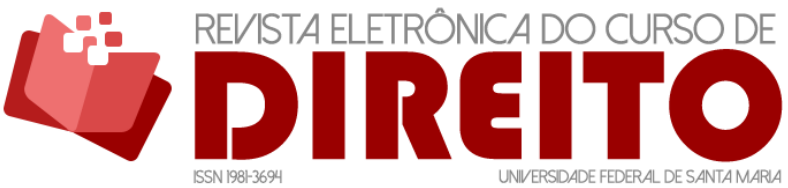

TRABALHO DECENTE SEGUNDO A OIT: UMA CONCEPÇÃO DEMOCRÁTICA? ANÁLISE CRÍTICA À LUZ DA TEORIA DO

CONTRATO SOCIAL

Silvio Beltramelli Neto ISADORA REZENDE BONAMIM JULIA DE CARVALHO VOLTANI

as the guideline for ILO actions, as well as at the state level, when the brazilian National Decent Work Agenda was elaborated. Finally, it can be concluded that the conceptions of Decent Work and the National Decent Work Agenda, despite not being undemocratic, can not be considered sufficiently democratic, due to the crisis of the Social Contract, which directly affects the pillars of representative democracy and the socially inclusive function of labor, with the consequent weakening of the representativeness of trade unions and the role of State as a normalizing agent of social inequalities. The methods used were the hypothetical-deductive approach and the historical and bibliographic process methods.

Keywords: National Decent Work Agenda; Social Contract; International Cooperation; Democracy; Decent Work.

\section{RESUMEN}

Desde la teoría del Contrato Social de Jean-Jacques Rousseau y le la percepción de Boaventura de Sousa Santos acerca de la actual crisis de esse Contrato, el articulo discute la naturaleza democrática de la adopción por la OIT de la concepción de Trabajo Decente, poniendo en cuestión el tripartismo y el diálogo social aplicados tanto en la escala internacional, cuando de la elección del Trabajo Decente como directriz de las acciones de la OIT, cuanto en la escala estatal, por ocasión de la elaboración de la Agenda Nacional del Trabajo Decente brasileña. Se concluye que las concepciones de Trabajo Decente y de la Agenda Nacional del Trabajo Decente brasileña, aunque no son antidemocráticas, también no pueden ser tomadas como suficientemente democráticas, ante la crisis del Contrato Social, que afecta, de manera directa, los pilares de la democracia representativa y de función socialmente incluida del trabajo, con la consiguiente fragilización de la representatividad de las entidades sindicales e del papel del Estado mientras agente reparador de las desigualdades sociales. Fueron usados el método de enfoque hipotético-deductivo y los métodos de procedimiento histórico y bibliográfico.

Palabras clave: Agenda Nacional del Trabajo Decente; Contrato Social. Cooperación Internacional; Democracia; Trabajo Decente.

\section{SUMÁRIO}

INTRODUÇÃO; 1 DEMOCRACIA E DIÁLOGO SOCIAL COMO ELEMENTOS SUBJACENTES DO TRABALHO DECENTE SEGUNDO A OIT; 2 NOÇÃO DE TRABALHO DECENTE: ENTRE O CONSENSO E A DISPUTA; 3 CONTRATO SOCIAL E DEMOCRACIA; 4 A DELIBERAÇÃO TRIPARTITE PARA O TRABALHO DECENTE NA PERSPECTIVA DA CRISE DO CONTRATO SOCIAL; 5 AGENDA NACIONAL DE TRABALHO DECENTE: DIÁLOGO SOCIAL DEMOCRÁTICO?; CONCLUSÃO; REFERÊNCIAS.

\section{INTRODUÇÃO}

Às portas do século XXI, a Organização Internacional do Trabalho (OIT) consagrou o Trabalho Decente seu eixo temático e prioritário para unificar as ações dos governos, trabalhadores, empregadores sob um pretenso marco civilizatório das relações de trabalho configuradas como estão nos tempos atuais.

A concepção de Trabalho Decente pugna, na esteira do tripartismo característico da OIT, pelo fortalecimento do diálogo social, compreendido como a interlocução entre Estado, representação patronal e representação obreira em múltiplos níveis, desde a cooperação e consultas tripartidas nacionais até a negociação coletiva na própria empresa. Demais disso, a deliberação tripartite que levou à adoção do Trabalho Decente como cerne das ações da OIT é tratada como expressão da democracia que alegadamente subjaz à própria concepção adotada. 
ISSN 1981-3694

(DOI): $10.5902 / 1981369433853$

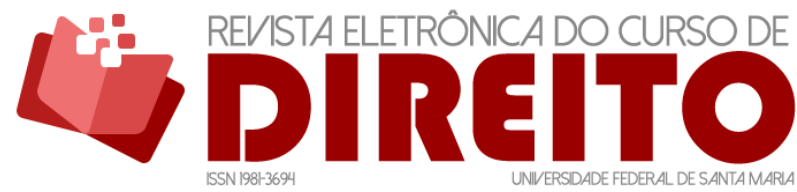

TRABALHO DECENTE SEGUNDO A OIT: UMA CONCEPÇÃO DEMOCRÁTICA? ANÁLISE CRÍTICA À LUZ DA TEORIA DO

CONTRATO SOCIAL

SiLvio BeltramelLi Neto

ISADORA REZENDE BONAMIM

JULIA DE CARVALHO VOLTANI

A partir da teoria do Contrato Social de Jean-Jacques Rousseau e da percepção de Boaventura de Sousa Santos acerca da hodierna crise desse Contrato enquanto cânone da modernidade ocidental, este artigo discute a natureza democrática da adoção pela OIT da concepção de Trabalho Decente, pondo em causa o tripartismo e o diálogo social aplicados tanto na escala internacional, quando da eleição do Trabalho Decente como diretriz central das ações da OIT, quanto na escala estatal, por ocasião da elaboração da Agenda Nacional do Trabalho Decente, encampada pelo Estado brasileiro. Frise-se que, acerca da Agenda brasileira, não é escopo desta reflexão realizar qualquer juízo sobre a pertinência de seu conteúdo, dado interessar-se tão somente pelo itinerário de sua elaboração.

Para tanto, este estudo valer-se-á do método de abordagem hipotético-dedutivo e dos métodos de procedimento histórico e bibliográfico, sobretudo pela análise de documentos oficiais da OIT, do Estado brasileiro e, naturalmente, de trabalhos doutrinários de interesse.

\section{DEMOCRACIA E DIÁLOGO SOCIAL COMO ELEMENTOS SUBJACENTES DO TRABALHO DECENTE SEGUNDO A OIT}

O Trabalho Decente foi proposto como um objetivo central das ações da OIT na $87^{\mathrm{a}}$ reunião da Conferência Internacional do Trabalho, em 1999, por Juan Somavia, o então DiretorGeral da entidade, que o fez diante da necessidade de adaptação e renovação da atuação daquela organização internacional frente às mudanças no contexto mundial pautadas pela liberalização econômica e pela mundialização que influenciam diretamente as relações laborais.

Para promover o Trabalho Decente, propôs-se a consecução, de forma harmônica e equilibrada, de quatro objetivos estratégicos: a promoção de direitos e princípios fundamentais do trabalho, a criação de novos empregos de qualidade, a proteção social e o diálogo social ${ }^{2}$.

A promoção dos direitos e princípios do trabalho enquanto objetivo do Trabalho Decente é dividido em três prioridades, quais sejam, promover a Declaração da OIT sobre Princípios e Direitos Fundamentais no Trabalho de 1998, intensificar a luta contra o trabalho infantil e, finalmente, renovar as atividades relativas às normas da OIT. Todas essas prioridades estão em ordem a preservar os princípios fundamentas e direitos no trabalho ${ }^{3}$. Ditos princípios assim são definidos pela Declaração de 1998: liberdade de associação e de organização sindical,

2 OIT. CONFERENCIA INTERNACIONAL DEL TRABAJO. $87^{\mathrm{a}}$ reúnion. Memoria Del Director General: Trabajo decente. Genebra: Oficina Internacional del Trabajo Ginebra, OIT, 1999, p. 06. Disponível em: http://www.ilo.org/public/spanish/standards/relm/ilc/ilc87/rep-i.htm. Acesso em: 12 jul. 2018.

3 Ibidem, p. 14. 
ISSN 1981-3694

(DOI): $10.5902 / 1981369433853$

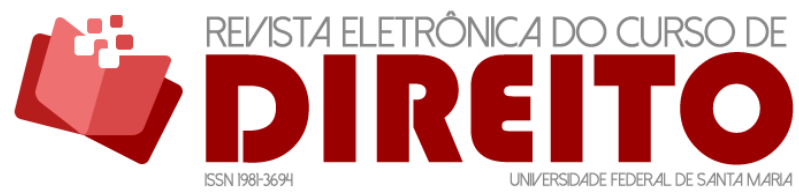

TRABALHO DECENTE SEGUNDO A OIT: UMA CONCEPÇÃO DEMOCRÁTICA? ANÁLISE CRÍTICA À LUZ DA TEORIA DO

CONTRATO SOCIAL

Silvio Beltramelui Neto ISADORA REZENDE BONAMIM JULIA DE CARVALHO VOLTANI

reconhecimento efetivo do direito de negociação coletiva, eliminação de todas as formas de trabalho forçado ou obrigatório, abolição efetiva do trabalho infantil e eliminação da discriminação em matéria de emprego e ocupação.

O segundo objetivo tem como principal elemento de atuação a criação de novos postos de empregos, contanto que dignos, remunerados, sem distinção de sexos, com a proteção necessária e com igualdade de condições de ingresso ${ }^{4}$.

A proteção social visa amortizar os efeitos das crises econômicas, garantindo amplo acesso a serviços básicos de sobrevivência, especialmente àqueles que não possuem condições de manter o próprio sustento, temporária ou permanentemente, por se encontrarem inaptos ao trabalho ou desempregados ${ }^{5}$.

O diálogo social é apresentado como um meio eficaz para a condução dos demais objetivos e indispensável para amortizar as tensões sociais, exigindo a participação e liberdade de associação, sendo, pois, reconhecido como um princípio organizador da OIT por meio do sistema tripartite ${ }^{6}$. A OIT admite uma dimensão regional do diálogo social, reconhecendo que mesmo sua definição sofre alterações de acordo com o local e período em que é dimensionado ${ }^{7}$.

Muito embora não reste claro o conceito de diálogo social, sendo um termo indefinido e aberto $^{8}$, é importante a compreensão do papel das negociações coletivas para o desenvolvimento da sociedade e da própria democracia, ao passo que, em nível nacional, a ampla participação dos interlocutores sociais reforça o processo e a legitimidade das políticas públicas. Segundo Uriarte, o diálogo social tem uma dimensão política que o transforma em um componente da democracia pluralista?.

No sistema de diálogo social tripartido, os interlocutores sociais (empregadores e trabalhadores) se relacionam de duas maneiras, através do conflito e da negociação, e contam

\footnotetext{
${ }^{4}$ OIT. CONFERENCIA INTERNACIONAL DEL TRABAJO. $87^{\mathrm{a}}$ reúnion. Memoria Del Director General: Trabajo decente, cit., p. 14.

${ }^{5}$ OIT. CONFERENCIA INTERNACIONAL DEL TRABAJO. 87 $7^{\text {a }}$ reúnion. Memoria Del Director General: Trabajo decente, cit., p. 32.

${ }^{6}$ OIT. CONFERENCIA INTERNACIONAL DEL TRABAJO. 87 ${ }^{\mathrm{a}}$ reúnion. Memoria Del Director General: Trabajo decente, cit., p. 07.

7 OIT. CONFERENCIA INTERNACIONAL DEL TRABAJO. 87ª reúnion. Memoria Del Director General: Trabajo decente, cit., p. 46.

8 URIARTE, Oscar Ermida. Diálogo social: teoría y práctica. Sindicatos y diálogo social: situación actual y perspectivas, v. 3, n. 120, p. 57, 2000, p. 261.

${ }^{9}$ URIARTE, Oscar Ermida. Diálogo social: teoría y práctica. Sindicatos y diálogo social: situación actual y perspectivas, v. 3, n. 120, p. 57, 2000, p. 263.
} 
ISSN 1981-3694

(DOI): $10.5902 / 1981369433853$

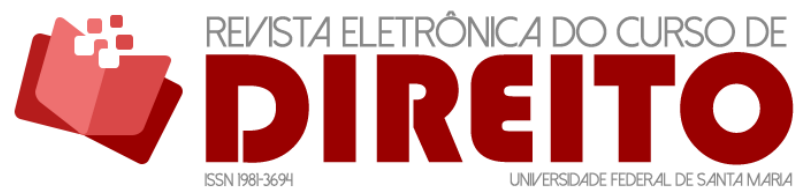

TRABALHO DECENTE SEGUNDO A OIT: UMA CONCEPÇÃO DEMOCRÁTICA? ANÁLISE CRÍTICA À LUZ DA TEORIA DO

CONTRATO SOCIAL

Silvio Beltramelli Neto ISADORA REZENDE BONAMIM JULIA DE CARVALHO VOLTANI

com a intervenção do governo como facilitador de suas relações e da criação de uma cultura do diálogo social ${ }^{10}$.

A concepção de Trabalho Decente foi explicitamente inspirada pela Declaração e Programa de Ação de Copenhague de 1995, resultante da Cúpula Mundial sobre Desenvolvimento Social, convocada pela ONU ${ }^{11}$. Sob esse paradigma, a OIT passa, pois, a propor a cooperação internacional dos diversos Estados e atores internacionais envolvidos com as questões econômicas e sociais sob as premissas arroladas do Desenvolvimento Social aplicadas às relações laborais. O desenvolvimento ganha, portanto, centralidade na condução da governança global em matéria laboral, sendo declarado questão transversal à concepção de Trabalho Decente ${ }^{12}$.

São exatamente as ideias do economista e filósofo indiano Amartya Sen sobre o Desenvolvimento Social que, segundo admitido pela própria OIT, vão influenciar a construção teórica da proposta de Trabalho Decente. O Desenvolvimento Social, sob a ótica de Sen, nasce da crítica ao desenvolvimento avaliado a partir de indicadores econômicos atrelados à acumulação de capital e ao crescimento econômico - v.g. o Produto Interno Bruto e a renda per capita -, propondo a consideração de outros critérios que revelem a melhora da qualidade de vida equitativamente distribuída ${ }^{13}$. Desde essa crítica, defende-se que o desenvolvimento humano somente é possível através da expansão das liberdades pessoais, que, por sua vez, ocorre com a remoção das fontes de privação, como a pobreza, a falta de acesso a infraestrutura pública e a negação de direitos civis, remoção essa que, necessariamente, depende de disposições sociais, econômicas e civis, e está estreitamente relacionada à participação democrática nas decisões políticas ${ }^{14}$.

Para a OIT, o tripartismo e o diálogo social ínsitos à ideia de Trabalho Decente garantem a participação e a democracia, contribuindo diretamente para o alcance dos demais objetivos

${ }^{10}$ ISHIKAWA, Junko. Aspectos clave del Diálogo Social Nacional: un documento de referencia sobre el Diálogo Social. Ginebra, Oficina Internacional del Trabajo, 2004, p. 07.

11 OIT. CONFERENCIA INTERNACIONAL DEL TRABAJO. 87ª reúnion. Memoria Del Director General: Trabajo decente, cit., p. 15.

12 OIT. CONFERENCIA INTERNACIONAL DEL TRABAJO. $89^{\text {a }}$ reúnion. Memoria del Director General - Reducir el Deficit del Trabajo Decente: un desafío global. Ginebra: OIT, 2001, p. 02. Disponível em: http://www.ilo.org/public/spanish/standards/relm/ilc/ilc89/pdf/rep-i-a.pdf. Acesso em: 12 jul. 2018.

${ }^{13}$ SEN, Amartya. Desenvolvimento como liberdade. Trad. Laura Teixeira Mota. São Paulo: Companhia das Letras, 2010, p. 28-29.

${ }^{14}$ SEN, Amartya. Desenvolvimento como liberdade. Trad. Laura Teixeira Mota. São Paulo: Companhia das Letras, 2010, p. 47. Nas palavras de Sen, "[...]a liberdade política em forma de democracia contribui para salvaguardar a liberdade econômica e a liberdade de sobreviver" (SEN, Amartya; NUSSBAUM, M. C. Alocución del Sr. Amartya Sen, Premio Nobel de Economía. 87ª. Conferencia Internacional del Trabajo, 1999, p. 7), razão pela qual, afirma o economista indiano não se ter notícia, na história, de que um surto significativo de fome coletiva tenha assolado qualquer país democrático, por mais pobre que seja (SEN, Amartya. Desenvolvimento como liberdade, cit., p. 76). 
ISSN 1981-3694

(DOI): $10.5902 / 1981369433853$

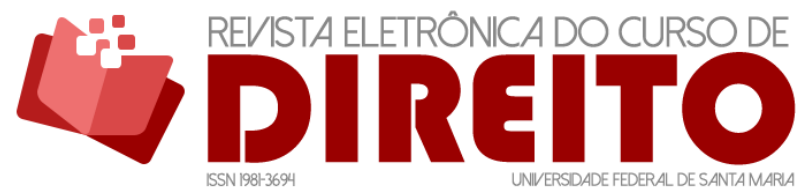

TRABALHO DECENTE SEGUNDO A OIT: UMA CONCEPÇÃO DEMOCRÁTICA? ANÁLISE CRÍTICA À LUZ DA TEORIA DO

CONTRATO SOCIAL

SiLvio Beltramelui Neto

ISADORA REZENDE BONAMIM

JULIA DE CARVALHO VOLTANI

traçados $^{15}$. De acordo com esta compreensão, o diálogo social afigura-se necessário para assegurar o livre exercício de participação e contribuição por parte de diversos setores sociais, com vistas à elaboração das políticas públicas e à consolidação democrática ${ }^{16}$.

A OIT adota uma definição própria de diálogo social, que abarca uma extensa variedade de processos e práticas verificadas em distintos países. Segundo tal definição, o diálogo social compreende todo tipo de negociações e consultas ou, simplesmente, o mero intercâmbio de informação entre governos, empregadores e trabalhadores sobre questões de interesse comum relativas às políticas econômicas e sociais ${ }^{17}$. São três as ferramentas de consecução do diálogo social consideradas pela OIT: negociações, consultas e intercâmbio de informações.

A negociação (coletiva) é a forma mais ampla de diálogo social, que faz dos atores partícipes ativos do processo decisório. A consulta pressupõe um diálogo mais a fundo entre os interlocutores; todavia, não dispõe de poder de decisão, conquanto possa embasá-la junto a quem dela se incumbe. Já o intercâmbio de informações é o processo mais básico de diálogo social, que não implica discussão ou ação sobre as questões enfrentadas, restringindo-se à troca de informações que prepara o caminho de um diálogo social mais maduro ${ }^{18}$.

Percebe-se, pois, que toda esta construção teórica alça a democracia ao patamar de condição de efetivação do Desenvolvimento Social e do Trabalho Decente, tendo no tripartismo e no diálogo social, segundo a OIT e parte da doutrina, as expressões de uma pretensa democracia deliberativa de suas ações.

\section{NOÇÃO DE TRABALHO DECENTE: ENTRE O CONSENSO E A DISPUTA}

Em que pese a adoção do Trabalho Decente por deliberação tripartite, sua construção não escapa a problematizações em razão da pouca discussão acerca de seu conteúdo (conceito) e de suspeitas lançadas à sua aceitação tranquila em um espaço deliberativo permeado pela tensão capital versus trabalho.

Esta absorção aparentemente acrítica do termo Trabalho Decente também se percebe no campo doutrinário, junto à produção interna e externa à OIT, no que tange ao conteúdo da

15 OIT. CONFERENCIA INTERNACIONAL DEL TRABAJO. $87^{\mathrm{a}}$ reúnion. Memoria Del Director General: Trabajo decente, cit., p. 14.

${ }^{16}$ LEVAGGI, Virgilio. Democracia y trabajo decente en América Latina. Lima: OIT, 2006, p. 33.

17 ISHIKAWA, Junko. Aspectos clave del Diálogo Social Nacional: un documento de referencia sobre el Diálogo Social. Ginebra, Oficina Internacional del Trabajo, 2004, p. 03.

${ }_{18}$ ISHIKAWA, Junko. Aspectos clave del Diálogo Social Nacional: un documento de referencia sobre el Diálogo Social. Ginebra, Oficina Internacional del Trabajo, 2004, p. 03. 
ISSN 1981-3694

(DOI): $10.5902 / 1981369433853$

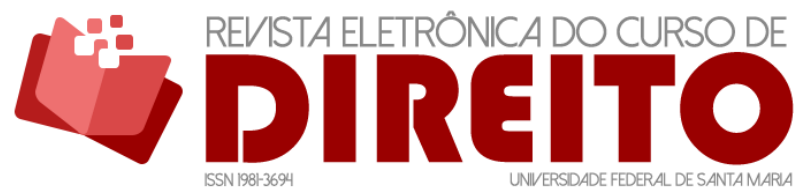

TRABALHO DECENTE SEGUNDO A OIT: UMA CONCEPÇÃO DEMOCRÁTICA? ANÁLISE CRÍTICA À LUZ DA TEORIA DO

CONTRATO SOCIAL

Silvio Beltramelui Neto

ISADORA REZENDE BONAMIM

JULIA DE CARVALHO VOLTANI

concepção de Trabalho Decente. Problematizando este aspecto, Sehncruch [et al.], a partir de uma comparação com o IDH (Índice de Desenvolvimento Humano), discorre sobre a inexistência de investigações acadêmicas, publicações ou qualquer participação internacional dedicada ao estudo e pesquisa do conceito Trabalho Decente, a fim de estreitar a sua concepção e seu modo de aplicabilidade, o que teria sido decisivo para o baixo impacto real sobre o desenvolvimento internacional das literaturas acerca do tema ${ }^{19}$.

Já no campo político-institucional da OIT, a despeito dos naturais conflitos interna corporis decorrentes de interesses quase sempre antagônicos, a concepção de Trabalho Decente, desde sua postulação por Juan Somavia, não apresentou firme oposição por nenhum dos integrantes do tripartismo. Na visão de Vosko, isso se deu porque o Trabalho Decente exprime um espaço hábil de mediação das tensões da $\mathrm{OIT}^{20}$. Menos otimista, a Subsecretaria de Programação Técnica de Estudos Laborais da Argentina entende que, embora seja o termo Trabalho Decente relativamente consensual, seu conteúdo valorativo é constantemente objeto de disputas.

Para a Subsecretaria argentina, apesar do consenso na adoção do Trabalho Decente, as perspectivas para cada uma das partes (empregadores, operários e governo) não são idênticas, isso porque, em 2002, o setor patronal, através da Organização Internacional dos Empregadores, pronunciou-se no sentido de que o Trabalho Decente não tem um teto e que varia de acordo com a realidade de cada país em que efetivamente é aplicado, levando em consideração a economia, cultura e política daquele local, gerando dificuldade para que se acorde acerca de como alcançar os objetivos estratégicos. Já a representação obreira, a despeito de louvar o Trabalho Decente, não raro, em nível local ou regional, associa o tema a alguma situação conjectural com uma demanda específica, suscitando, pois, distintos padrões de compreensão do instituto ${ }^{21}$.

Percebe-se que, se os objetivos traçados para a busca do Trabalho Decente, como visto, são bem delimitados pela OIT, a questão do sentido e do conteúdo dessa concepção ainda é sobremaneira tormentosa, o mesmo se podendo dizer sobre o monitoramento das ações

SEHNBRUCH, Kirsten; BURCHEL, Brendan; AGLONI, Nurjk; PIASNA, Agnieska. Human development and decent work: why some concepts succeed and others fail to make an impact. Development and Change, v. 46, n. 2, p. 197-224, 2015, p. 204.

20 VOSKO, LeahF. "Decent Work". The Shifting Role of the ILO and the Struggle for Global Social Justice. Global Social Policy Canada, v. 2, p.19-46, 2002, p. 20.

${ }^{21}$ ARGENTINA. MINISTERIO DEL TRABAJO, EMPLEO Y SEGURIDAD SOCIAL. Trabajo decente: significados y alcances del concepto. Indicadores propuestos para su medición. Buenos Aires: Ministerio del Trabajo, Empleo y Seguridad Social, 2005, p. 116-117. Disponível em: http://trabajo.gob.ar/downloads/biblioteca_estadisticas/toe03_07trabajo-decente.pdf. Acesso em: 12 jul. 2018. 
ISSN 1981-3694

(DOI): $10.5902 / 1981369433853$

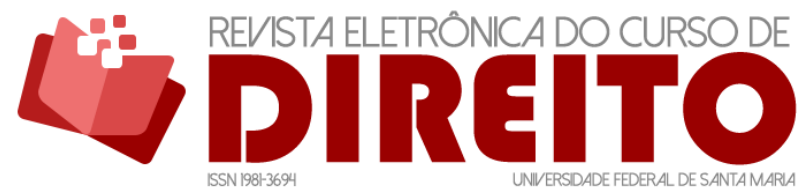

TRABALHO DECENTE SEGUNDO A OIT: UMA CONCEPÇÃO DEMOCRÁTICA? ANÁLISE CRÍTICA À LUZ DA TEORIA DO

CONTRATO SOCIAL

Silvio Beltramelui Neto ISADORA REZENDE BONAMIM JULIA DE CARVALHO VolTANI

empreendidas para o alcance de seus escopos estratégicos. O histórico de documentos oficiais produzidos pela OIT após 1999 - data da consagração institucional do termo "Trabalho Decente" - denotam a enunciação de uma concepção propositalmente sem definição conotativa fechada.

A descrição ideal mais comum de Trabalho Decente, encontrada nos escritos oficiais da OIT, atrela-o aos seus quatro aludidos objetivos estratégicos, como fez, à partida, seu proponente Juan Somavia. No ano seguinte, também em Memória do Diretor-Geral à Conferência Internacional do Trabalho, definiu-se Trabalho Decente como uma atividade desempenhada em condição de liberdade, equidade, segurança e dignidade humana e que seja compatível com os direitos básicos enunciados na Constituição da OIT, na Declaração da OIT sobre os Princípios e Direitos Fundamentais no Trabalho de 1998 e nas demais normas da OIT $^{22}$.

Já em 2001, Somavia tratou o Trabalho Decente como uma "meta móvel”, um objetivo que evolui à medida em que se transformam as possibilidades, as circunstâncias e as prioridades de cada sociedade, sendo que seus valores mínimos avançam com o progresso econômico e social $^{23}$. À época, afirmou a representante do Estado neozelandês na Conferência acerca da fala do Diretor-Geral que se falta clareza ao que se deve entender por Trabalho Decente, ao menos existe consenso sobre serem os princípios enunciados na Declaração da OIT sobre os Princípios e Direitos Fundamentais no Trabalho um patamar mínimo a ser observado ${ }^{24}$, ao que respondeu Somavia, afirmando que, tal como verificado com desenvolvimento sustentável, o Trabalho Decente não requer "definição de dicionário", sendo uma formulação que abarca um significado a ser utilizado e entendido em muitos contextos culturais e de desenvolvimento distintos ${ }^{25}$.

Pode-se dizer, pois, que, em termos conceituais - com consequências para seu acompanhamento por meio de indicadores -, ainda paira proposital cizânia sobre o Trabalho Decente, provocando dúvida sobre o proveito desta abertura de conteúdo, em se considerando as nuances regionais de compreensão e ação relacionadas à ideia ${ }^{26}$.

22 OIT. CONFERENCIA INTERNACIONAL DEL TRABAJO. 88a reúnion. Memoria del Director General: Anexo: Informe sobre la situación de los trabajadores en los territorios árabes ocupados. Ginebra: OIT, 2000. Disponível em: http://www.ilo.org/public/spanish/standards/relm/ilc/ilc88/rep1a-a.htm. Acesso em: 12 jul. 2018.

${ }^{23}$ OIT. CONFERENCIA INTERNACIONAL DEL TRABAJO. $89^{\mathrm{a}}$ reúnion. Memoria del Director General - Reducir el Deficit del Trabajo Decente: un desafío global, cit.

${ }^{24}$ OIT. Discusión del informe del Presidente del Consejo de Administración y de la Memoria del Director General (cont.): OIT, 2001b. Disponível em: http://www.ilo.org/public/spanish/standards/relm/ilc/ilc89/pdf/pr-5s4.pdf. Acesso em: 12 jul. 2018.

25 OIT. CONFERENCIA INTERNACIONAL DEL TRABAJO. 89 ${ }^{a}$ reúnion. Actas Provisionales: Respuesta del Director General a la discusión de su Memoria: OIT, 2001. Disponível em: http://www.ilo.org/public/spanish/standards/relm/ilc/ilc89/pdf/pr-5s4.pdf. Acesso em: 12 jul. 2018.

${ }^{26}$ A doutrina propõe-se a se ocupar desta lacuna. Para uma tentativa de reconhecimento de "palavraschave" do conteúdo de Trabalho Decente, cf. BARRETTI GHIONE, Hugo. Concepto y dimensiones del 
ISSN 1981-3694

(DOI): $10.5902 / 1981369433853$

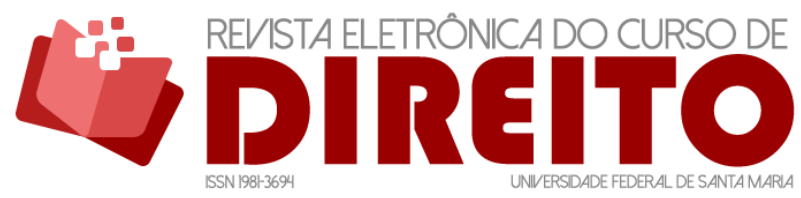

TRABALHO DECENTE SEGUNDO A OIT: UMA CONCEPÇÃO DEMOCRÁTICA? ANÁLISE CRÍTICA À LUZ DA TEORIA DO

CONTRATO SOCIAL

Silvio Beltramelui Neto

ISADORA REZENDE BONAMIM

JULIA DE CARVALHO VOLTANI

0 fato é que representantes nacionais de Estados, empregados e empregadores, reunidos em assembleia, em 1999 e nos anos seguintes, encamparam a proposta de Somavia e não se opuseram, ao menos de forma explícita e eloquente, ao estabelecimento do Trabalho Decente como eixo das atividades da OIT, dali em diante, a despeito de sua abertura conceitual.

Bem por isso e considerando que a OIT trata seu sistema tripartite de deliberações, contextualizado pela noção de diálogo social, como instrumento de mediação democrática de interesses, cabe indagar: porque observado o procedimento básico triparte de deliberação da OIT, a concepção de Trabalho Decente é democrática? O enfrentamento sério desta questão exige preliminar posicionamento acerca do que se entende por democracia.

\section{CONTRATO SOCIAL E DEMOCRACIA}

O problema do caráter democrático do movimento de concepção do Trabalho Decente já foi, de algum modo, intuído por Trebilcock, para quem, embora seja a democracia representativa uma das ideias básicas em torno da cooperação tripartite, há que se reconhecer que a participação de representantes de alguns grupos neste processo deliberativo, mas não de outros, inevitavelmente dá lugar a perquirições sobre a equidade do tripartismo ${ }^{27}$.

Adverte Aieta que a busca por uma definição etimológica de democracia há que considerar que essa expressão admite exame sob duas perspectivas, quais sejam, uma descritiva (analítica) e outra prescritiva (axiológica). Nesta linha, a distinção entre democracia direta (Grécia clássica) e democracia representativa (“moderna”) e suas formas de operação pertencem à perspectiva descritiva, enquanto que os modelos democráticos liberal e socialista comportam indagação dentro da perspectiva prescritiva ${ }^{28}$.

A análise da democracia representativa como "forma de governo" pode ser atribuída a Heródoto, ao tratar do sorteio de "magistrados" como forma de nomeação de grupo designado para a tomada de decisão, no exercício da representação do povo. Todavia, coube a Rousseau

trabajo decente. Derecho laboral, tomo XLIV, n. 204, oct./dic. 2001, Montevideo, p. 695-716. Já para críticas e propostas sobre indicadores de acompanhamento das políticas públicas de efetivação de Trabalho Decente, cf. GHAI, Dharam. Decent work: concept and indicators. International Labour Review, Genebra, v. 142, n. 2, 113-145, 2003.

27 TREBILCOCK, Anne. Towards social dialogue: Tripartite cooperation in national economic and social policy-making. Ginebra: OIT, 1994, p. 7 e 9.

${ }^{28}$ AIETA, Vânia S. Democracia. In: BARRETO, Vicente de P. (Coord.). Dicionário de filosofia do direito. São Leopoldo/Rio de Janeiro: Editora Unisinos; Livraria Editora Renovar, 2009, p. 191-192. 
ISSN 1981-3694

(DOI): $10.5902 / 1981369433853$

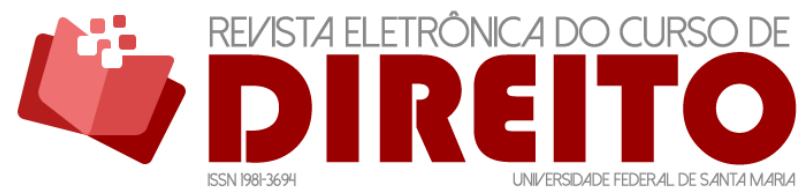

TRABALHO DECENTE SEGUNDO A OIT: UMA CONCEPÇÃO DEMOCRÁTICA? ANÁLISE CRÍTICA À LUZ DA TEORIA DO

CONTRATO SOCIAL

Silvio Beltramelui Neto ISADORA REZENDE BONAMIM JULIA DE CARVALHO VOLTANI

categorizar as formas de governo ${ }^{29}$, tendo-o feito sob inspiração solidarista subjacente à noção de Contrato Social (ou Pacto Social).

A teoria do Contrato Social segundo Rousseau decorre da visão desse filósofo sobre a vida em sociedade como algo que contraria o estado de natureza do ser humano, explicação encontrada na obra "Discurso sobre a origem e os fundamentos da desigualdade entre os homens", de 1750. Sob tal perspectiva, todo indivíduo tomado em seu "estado selvagem" é naturalmente forjado para a vida solitária e entregue à saciedade de suas necessidades, obtida mediante a interação permanente com a natureza e esporádica e pontual com seus semelhantes (inclusive descendentes), circunstância em que "todas as coisas funcionam de maneira tão uniforme e a face da Terra nunca se encontra sujeita a essas mudanças bruscas e contínuas, causadas pelas paixões e inconstância dos povos reunidos"30.

Partindo-se da premissa segundo a qual o estado humano de natureza não demanda vida em sociedade, nesse mesmo estado não há relação moral entre os indivíduos, tampouco amor moral (apenas físico), comércio e propriedade, elementos típicos da vida social, que consigo trazem outras tantas situações de sofrimento impensáveis para o homem selvagem ${ }^{31}$. Aliás, a propriedade (exercida originalmente em face do local de moradia), a família (espaço de diferenciação social entre homem e mulher) e a exploração do trabalho são as marcas da vida em sociedade que, ao se afirmarem como critérios para um sistema de preferências pessoais, instalaram um contexto de desigualdade sustentado por um Estado e por leis postos em função da perpetuação de tais privilégios ${ }^{32}$.

Entretanto, como salienta Saes, Rousseau nunca foi arauto do retorno do ser humano ao estado de natureza, por entender que o processo depravado da vida em sociedade era irreversível, pessimismo ao qual, por outro lado, fazia face um otimismo vindo da constatação de que a bondade inerente ao indivíduo, conquanto arrefecida pela socialização, poderia ser reavivada, a partir da ressignificação das relações sociais em novas bases: o Contrato Social ${ }^{33}$.

\footnotetext{
${ }^{29}$ AIETA, Vânia S. Democracia. In: BARRETO, Vicente de P. (Coord.). Dicionário de filosofia do direito. São Leopoldo/Rio de Janeiro: Editora Unisinos; Livraria Editora Renovar, 2009, p. 191.

30 ROUSSEAU, Jean-Jaques. Discurso sobre a origem e os fundamentos da desigualdade entre os homens. Trad. Laurent de Saes. São Paulo: Edipro, 2015, p. 62.

31 ROUSSEAU, Jean-Jaques. Discurso sobre a origem e os fundamentos da desigualdade entre os homens. Trad. Laurent de Saes. São Paulo: Edipro, 2015, p. 80-81 e 86-87.

32 ROUSSEAU, Jean-Jaques. Discurso sobre a origem e os fundamentos da desigualdade entre os homens. Trad. Laurent de Saes. São Paulo: Edipro, 2015, p. 95-113.

${ }_{33}$ SAES, Laurent de. Introdução ao Discurso sobre a origem e os fundamentos da desigualdade entre os homens. Trad. Laurent de Saes. São Paulo: Edipro, 2015, p. 23.
} 
ISSN 1981-3694

(DOI): $10.5902 / 1981369433853$

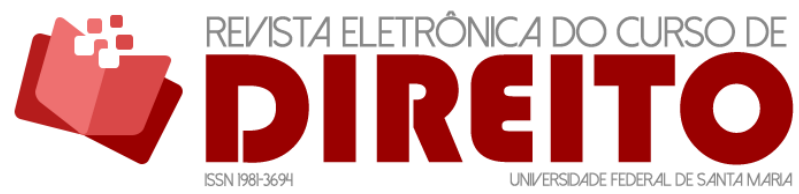

TRABALHO DECENTE SEGUNDO A OIT: UMA CONCEPÇÃO DEMOCRÁTICA? ANÁLISE CRÍTICA À LUZ DA TEORIA DO

CONTRATO SOCIAL

Silvio Beltramelui Neto

ISADORA REZENDE BONAMIM

JULIA DE CARVALHO VOLTANI

A construção da teoria do Contrato Social acaba por se consolidar como teoria política desdobrada das constatações consignadas no "Discurso" de 1750, no qual Rousseau sustentou a existência de dois princípios da natureza humana anteriores à sua racionalização e sociabilidade, quais sejam, o princípio de autopreservação e bem-estar e o princípio da repugnância ao perecimento do semelhante (piedade) ${ }^{34}$. Por força desse último, no estado de natureza não há servidão, porquanto a orientação do indivíduo unicamente por suas necessidades vitais não haveria de deixar espaço para subjugação imposta pela lei do mais forte ${ }^{35}$.

O Contrato Social é, antes de tudo, um ato de associação orientado à autopreservação, pois a vida em sociedade é, prima facie, predatória ao ser humano. Na impossibilidade de que novas forças "extra-humanas" reguladoras sejam criadas, impende a agregação das forças de cada indivíduo, a resultar uma soma harmônica de forças dirigidas. Busca-se, assim, um sistema de organização social "que defenda e proteja com toda a força comum a pessoa e os bens de cada sócio, e pela qual, unindo-se cada um a todos, não obedeça todavia senão a si mesmo e que fique tão livre como antes" 36 .

O traço solidarista e essencialmente inclusivo do Contrato Social evidencia-se na enunciação que Rousseau emprega para definir a essência do Pacto idealizado: “Cada um de nós põe em comum sua pessoa e todo o seu poder sobre a suprema direção da vontade geral, e recebemos enquanto corpo cada membro como parte indivisível do todo" ${ }^{37}$.

Segue-se que tal associação enseja um "corpo moral e coletivo", produto da soma dos interesses comuns de todas as pessoas que o compõe, por isso que corpo coletivo (Soberano) e as individualidades jamais poderão ter, por princípio, interesses colidentes ${ }^{38}$. Importa notar que o Contrato Social, segundo o seu autor, não é produto da renúncia à liberdade, como em Hobbes, senão a única maneira de maximizá-la na vida em sociedade ${ }^{39}$.

34 ROUSSEAU, Jean-Jaques. Discurso sobre a origem e os fundamentos da desigualdade entre os homens. Trad. Laurent de Saes. São Paulo: Edipro, 2015, p. 47-48.

35 ROUSSEAU, Jean-Jaques. Discurso sobre a origem e os fundamentos da desigualdade entre os homens. Trad. Laurent de Saes. São Paulo: Edipro, 2015, p. 92.

36 ROUSSEAU, Jean-Jaques. Do contrato social. Trad. Pietro Nassetti. São Paulo: Martin Claret, 2004, p. 31.

${ }^{37}$ ROUSSEAU, Jean-Jaques. Do contrato social. Trad. Pietro Nassetti. São Paulo: Martin Claret, 2004, p. 32.

38 ROUSSEAU, Jean-Jaques. Do contrato social. Trad. Pietro Nassetti. São Paulo: Martin Claret, 2004, p. 32-33.

39 SANTOS, Boaventura de S. A crítica da razão indolente: contra o desperdício da experiência. 2 ed. Porto: Edições Afrontamento, 2002, p. 121. 
ISSN 1981-3694

(DOI): $10.5902 / 1981369433853$

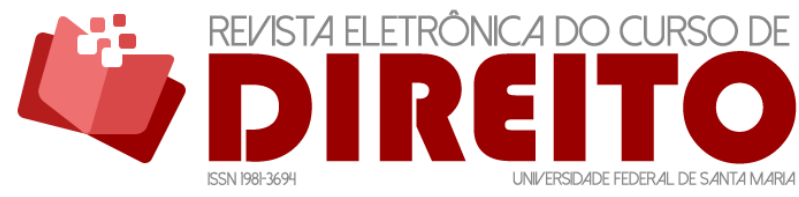

TRABALHO DECENTE SEGUNDO A OIT: UMA CONCEPÇÃO DEMOCRÁTICA? ANÁLISE CRÍTICA À LUZ DA TEORIA DO

CONTRATO SOCIAL

Silvio Beltramelui Neto

ISADORA REZENDE BONAMIM

JULIA DE CARVALHO VolTANI

O Soberano é, por definição, o porta-voz da vontade geral, a qual não se confunde com a vontade de todos, embora resulte de sua média ${ }^{40}$. A primeira só compreende 0 interesse comum e, por isso, tão somente põe-se ao proveito do bem comum; a última, de seu turno, não passa de uma soma de vontades particulares.

Sob tais premissas, o Soberano poderá confiar o governo a todos os indivíduos, a uma parcela deles ou a apenas uma pessoa, consubstanciando, respectivamente, as formas de governo democrática (no sentido grego clássico), aristocrática e monárquica ${ }^{41}$. A aristocracia suporta os tipos natural (por decorrência da ordem social), eletiva e hereditária. Para Rousseau, uma democracia direta verdadeira jamais existiu ou existirá, posto não ser da natureza das coisas que um grande grupo governe um pequeno grupo; já a aristocracia eletiva é a melhor dentre as três modalidades aristocráticas ${ }^{42}$. A aristocracia eletiva de Rousseau evidencia, pois, a base da compreensão moderna do que se conhece por democracia representativa, presente no foro decisório da OIT, porquanto composto por representantes de Estados e de entidades sindicais de empregados e de empregadores que ali se manifestam e deliberam sob a legitimidade formal do voto.

Todavia, a percepção de que a democracia, em sua feição moderna, portanto representativa, circunscreve-se ao voto, como adverte Boaventura de Sousa Santos, com apoio em Kant, é reducionista e perigosamente justificadora da teoria liberal, em completo desacordo com o viés solidarista (comunitarista) da proposta de Rousseau. O sociólogo português lembra que o Contrato Social rousseauniano não se compatibiliza com a representação de democracia segundo a teoria liberal da prevalência quantitativa das intenções manifestadas no voto majoritário, haja vista que o governo exercido pelos representantes eleitos deve fazer coincidir a vontade coletiva dos particulares com a vontade geral consubstanciadora do Soberano. Daí que “o contrato social se assenta, não numa obrigação política vertical cidadão-Estado, como sucede no modelo liberal, mas antes numa obrigação política horizontal cidadão-cidadão, na base da qual é possível fundar uma associação política participativa"³.

40 "[...] quando [se] tira dessas vontades [particulares] as mais e as menos, que mutuamente se destroem, resta por soma das diferenças a vontade geral" (ROUSSEAU, Jean-Jaques. Do contrato social, cit., p. 41). "[...] no contrato social, a vontade individual pode ser boa ou má, mas a vontade geral só pode ser boa" (SANTOS, Boaventura de S. A crítica da razão indolente: contra o desperdício da experiência, cit., p. 121).

${ }^{41}$ ROUSSEAU, Jean-Jaques. Do contrato social. Trad. Pietro Nassetti. São Paulo: Martin Claret, 2004, p. 69-70.

42 ROUSSEAU, Jean-Jaques. Do contrato social. Trad. Pietro Nassetti. São Paulo: Martin Claret, 2004, p. 71-74.

${ }^{43}$ SANTOS, Boaventura de S. Pela mão de Alice: o social e o político na pós-modernidade. São Paulo: Cortez, 2013, p. 228. 
ISSN 1981-3694

(DOI): $10.5902 / 1981369433853$

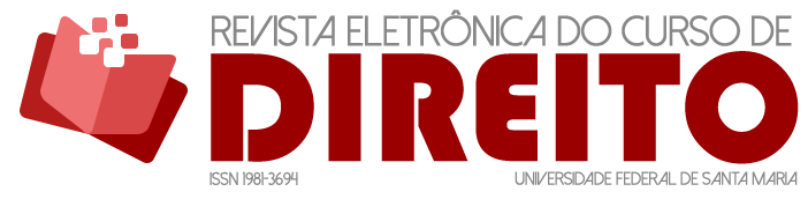

TRABALHO DECENTE SEGUNDO A OIT: UMA CONCEPÇÃO DEMOCRÁTICA? ANÁLISE CRÍTICA À LUZ DA TEORIA DO

CONTRATO SOCIAL

Silvio Beltramelui Neto ISADORA REZENDE BONAMIM JULIA DE CARVALHO VOLTANI

Não obstante, o discurso dominante da teoria liberal concebe a sociedade civil como espaço de um associativismo voluntário, baseado em igualdade plena de exercício de liberdade, autonomia e interesses de todos os indivíduos, ocultando, pois, a desigualdade material inerente ao capitalismo, que acomete e direciona a própria formação de vontade individual, seja no espaço da produção, seja no das relações privadas patriarcais ${ }^{44}$. Tal ocultação favorece a percepção ilusória segundo a qual a democracia se perfaz, integralmente, com a faculdade do voto, escondendo as relações de poder e dominação que de fato permeiam a própria formação da vontade do votante, a dissociar as vontades de Soberano e Governo.

Este entendimento encontra-se contextualizado por uma ideia de crise do Contrato Social enquanto "paradigma social, político e cultural" da modernidade ocidental, baseado na liberdade, na igualdade, na autonomia, na subjetividade, na justiça e na solidariedade, valores convertidos em promessas não cumpridas pela própria modernidade. Tal crise minou a coesão subjacente à vontade geral, fazendo-a dissipar-se, ante a perda da centralidade do Estado e do direito estatal como artífices da regulação face à instantaneidade dos interesses do mercado financeiro globalizado, que impulsiona um tempo de contratualização eminentemente liberalindividual e efêmera, conformando uma espécie de "Contrato Social Neoliberal” ou "Contrato Social Pós-Moderno Leonino", onde predomina a exclusão social aos processos inclusivos ${ }^{45}$. Este contexto atinge, por óbvio, a democracia representativa, enquanto instrumento operacional do Contrato Social tão prestigiado, atualmente.

Está-se a sofrer, consequentemente, um fenômeno de desinstitucionalização da democracia, em função da crise de representação e de participação ${ }^{46}$, fenômeno esse que não se restringe ao Estado, mas também à esfera não-estatal, o que encampa os sindicatos ${ }^{47}$.

Por óbvio, não se está a desmerecer o papel do voto como instrumento de operacionalização da democracia, mas apenas a problematizar a redução da democracia à possibilidade do voto, algo a ser refletido nas diversas instituições públicas e privadas, tanto locais como globais, que admitem o modelo representativo, incluindo a OIT.

“O capitalismo não é criticável por não ser democrático mas por não ser suficientemente democrático", afirma Boaventura, reconhecendo que "a democracia

\footnotetext{
${ }^{44}$ SANTOS, Boaventura de S. Pela mão de Alice: o social e o político na pós-modernidade. São Paulo: Cortez, 2013, p. 229.

${ }^{45}$ SANTOS, Boaventura de S. A gramática do tempo: para uma nova cultura política. 2. ed. Porto: Edições Afrontamento, 2010, p. 301-304.

${ }^{46}$ SANTOS, Boaventura de $\mathrm{S}$. The resilience of abyssal exclusions in our societies: toward a post-abyssal law. Tilburg Law Review, v. 22, n. 1-2, p. 237-258, 2017, p. 247.

${ }^{47}$ SANTOS, Boaventura de S. A gramática do tempo: para uma nova cultura política. 2. ed. Porto: Edições Afrontamento, 2010, p. 346 e 354.
} 
ISSN 1981-3694

(DOI): 10.5902/1981369433853

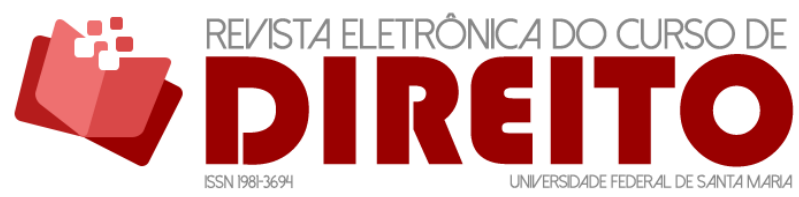

TRABALHO DECENTE SEGUNDO A OIT: UMA CONCEPÇÃO DEMOCRÁTICA? ANÁLISE CRÍTICA À LUZ DA TEORIA DO

CONTRATO SOCIAL

Silvio Beltramelui Neto

ISADORA REZENDE BONAMIM

JULIA DE CARVALHO VolTANI

representativa constituiu até agora o máximo de consciência política possível no capitalismo" e, em vista disso, se faz necessária a renovação da teoria democrática para que tenha aspirações emancipatórias frente às dominações vigentes, o que só cabe vislumbrar a partir da superação da ideia de que o ato de votar encerra em si a plenitude da participação política democrática ${ }^{48}$.

Esta renovação passa por disputas democráticas em três espaços de poder e que, por isso, são políticos: espaço doméstico, o espaço mundial e o espaço da produção.

O espaço doméstico patriarcal demanda disputa que vem sendo capitaneada pelo movimento feminista, no sentido da superação da discriminação sexual pela ampliação da presença feminina nos diversos loci de orientação das relações privadas.

O espaço mundial suscita o enfrentamento da histórica relação de troca sociológica (mais ampla que a econômica, englobando-a) desigual entre países centrais, periféricos e semiperiféricos, pautada pela forma dominante de poder pela qual se constituem as relações políticas internacionais, verificadas também no seio das organizações internacionais. E que bem se compreenda: as relações políticas internacionais não se resumem à interação entre EstadosNações, mas também e sobretudo, entre grandes corporações transnacionais e entre essas e aqueles. Neste último caso, é condição para a nova teoria democrática que também os espaços internacionais de deliberação assumam a politização das práticas transnacionais como meio de descortinar as relações de poder que the são subjacentes, a partir do que se poderá avançar nas disputas por ampliação da participação política democrática orientada a dar voz ao Soberano ${ }^{49}$.

Já o espaço da produção exige a hercúlea reversão de toda a desagregação da consciência de classe, a começar pela retomada da percepção de sua natureza política (negada pelo ideário liberal-capitalista) e, por conseguinte, pela sua (re)contextualização dentro de um espectro maior, o da cidadania, a fazer com que debates e decisões afetas às relações de trabalho travem-se em arena social mais ampla (não apenas das comissões de fábrica e dos sindicatos), a envolver inclusive aspectos ecológicos da relação homem e natureza, pautada pela exploração orientada à produção ${ }^{50}$.

Não obstante, circunstancialmente, convém a esta reflexão, de viés crítico, menos as alternativas à crise do Contrato Social do que a clareza quanto aos seus delineamentos, aplicados ao objeto de estudo.

\footnotetext{
48 SANTOS, Boaventura de S. Pela mão de Alice: o social e o político na pós-modernidade. São Paulo: Cortez, 2013, p. 269-270.

49 SANTOS, Boaventura de S. Pela mão de Alice: o social e o político na pós-modernidade. São Paulo: Cortez, 2013, p. 275-277.

50 SANTOS, Boaventura de S. Pela mão de Alice: o social e o político na pós-modernidade. São Paulo: Cortez, 2013, p. 272-275.
} 


\section{A DELIBERAÇÃO TRIPARTITE PARA O TRABALHO DECENTE NA PERSPECTIVA DA CRISE DO CONTRATO SOCIAL}

Para Rousseau, o trabalho é o único fator de legitimação da propriedade, de modo que sua dissociação marca o distanciamento do estado de natureza pela subjugação do ser humano pelo seu próximo, portanto fator da desigualdade que se instala da passagem do "homem selvagem" ao ser humano sociabilizado ${ }^{51}$. Depreende-se da teoria do Contrato Social que a desigualdade marcada pela subjugação atinente ao trabalho deve ser alvo da intervenção do Estado por meio de seus instrumentos regulatórios conferidos pelo Soberano, na medida em que, por definição, sua perpetuação, ao não se coadunar com o bem comum, não pode ser cogitada como reivindicação da vontade geral enquanto interesse médio dos particulares.

A propósito da crise do Contrato Social, há que se reconhecer a marginalização do princípio da comunidade enquanto pilar da regulação social ${ }^{52}$. Neste contexto, o protagonismo da contratualização solidária cede lugar à ênfase à contratualização (neo)liberal fugaz entre indivíduos, sendo que, sob a aparência do contrato, reemergem "princípios de ordenação hierárquica pré-moderna" favorecedores dos processos de exclusão em prejuízo dos processos de inclusão social ${ }^{53}$, ou seja, intensificando um quadro que admite que indivíduos não integrem, de fato, o Contrato Social, ao deixarem de participar da formação da vontade geral, algo obviamente contraditório à luz da teoria rousseauniana. Afinal, se a vontade é geral, não haveria que se admitir a condição de excluído a quem quer que fosse.

Diante deste panorama, afirma-se o primado do direito e dos tribunais liberais, marcadamente adeptos da contratualização individual e, por conseguinte, refreadores da contratualização social, a transformar o trabalho e seu direito correlato, antes espaço de cidadania (participação no Contrato Social), em espaço de exclusão, ou como prefere

51 “[...] é impossível conceber a ideia de propriedade nascendo de algo que não a mão de obra, pois não se vê o que, para apropriar-se das coisas que não fez, pode o homem acrescentar-lhes, além de seu trabalho. É unicamente o trabalho que, dando ao cultivador o direito sobre o produto da terra que lavrou, confere-lhe, por conseguinte, outro sobre o solo, ao menos até a colheita, e assim, de ano em ano, constituindo-se uma posse contínua, esta se transforma tranquilamente em propriedade" (ROUSSEAU, Jean-Jaques. Discurso sobre a origem e os fundamentos da desigualdade entre os homens. Trad. Laurent de Saes. São Paulo: Edipro, 2015, p. 106-107).

52 SANTOS, Boaventura de S. Do pós-moderno ao pós-colonial. E para além de um e de outro. Travessias, n. 6/7, p. 15-36, 2008, p. 17.

${ }^{53}$ SANTOS, Boaventura de $S$. A gramática do tempo: para uma nova cultura política. 2. ed. Porto: Edições Afrontamento, 2010, p. 304. 
ISSN 1981-3694

(DOI): $10.5902 / 1981369433853$

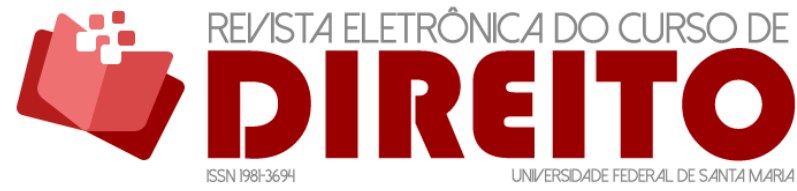

TRABALHO DECENTE SEGUNDO A OIT: UMA CONCEPÇÃO DEMOCRÁTICA? ANÁLISE CRÍTICA À LUZ DA TEORIA DO

CONTRATO SOCIAL

Silvio Beltramelui Neto

ISADORA REZENDE BONAMIM

JULIA DE CARVALHO VOLTANI

Boaventura, de “lumpen-cidadania"54. A exclusão fragmenta a sociedade, deixando-a "dividida que está em muitos apartheids e polarizada segundo eixos econômicos, sociais, políticos e culturais", tornando a ideia de vontade geral uma "proposta absurda"55.

No campo das relações de trabalho, é crível associar o processo de fragmentação social à antes referida desagregação contra a qual a disputa democrática no espaço da produção deve ser travada e que causou impacto direto na participação política da classe trabalhadora nos espaços de decisão da produção, já naturalmente reduzidos pela desigualdade ínsita à relação laboral. Esta desagregação teve um itinerário bastante conhecido, que remete à transformação vivenciada pelo capitalismo, desde meados do século passado, consubstanciada no processo de transmutação do capitalismo de mera acumulação em capitalismo de acumulação flexível ${ }^{56}$.

Em meados da década de sessenta, o modelo econômico vigente de acumulação começa a dar os primeiros sinais de saturação, vindo a ocasionar intensa crise capitalista, que teve como causa imediata os excessos do fordismo e da produção massificada, com prejuízo ao trabalho, pela supressão de sua dimensão criativa ${ }^{57}$. Mais precisamente entre 1965 e 1973, aflora a incapacidade do sistema fordista de produção e da concepção econômica keynesiana de contenção das contradições capitalistas, especialmente em razão da rigidez de um capital fixo de larga escala e de longo prazo, acumulado junto aos donos dos meios de produção. Favoreceu, decisivamente, este quadro de rigidez a atividade produtiva em massa e em larga escala, aliada à intensa defesa organizada dos contratos de trabalho, empreendida, segundo Hobsbawm pela "força aparentemente invencível do poder profundamente entrincheirado da classe trabalhadora - o que explica a onda de greves e os problemas trabalhistas do período 1968-1972", período no qual o movimento sindical, ainda que temporariamente, logrou resgatar os quatro aspectos fundamentais do sindicalismo clássico (ao estilo francês pré-século XX): "uma atitude, uma técnica, uma estratégia e uma esperança"58.

Em oposição àquela rigidez paralisante, o capitalismo de acumulação flexível é marcado pela flexibilidade também de processos de trabalho, de mercados de trabalho, dos produtos e,

\footnotetext{
${ }^{54}$ SANTOS, Boaventura de S. Do pós-moderno ao pós-colonial. E para além de um e de outro. Travessias, n. $6 / 7$, p. 15-36, 2008, p. 307.

55 SANTOS, Boaventura de S. Poderá o direito ser emancipatório? Revista Crítica de Ciências Sociais, n. 65, p. 03-76, 2003, p. 13.

${ }^{56}$ HARVEY, David. A condição pós-moderna. Trad. Adail Ubirajara Sobral e Maria Stela Gonçalves. 13. ed. São Paulo: Loyola, 2004, p. 135-140.

57 ANTUNES, Ricardo. Adeus ao trabalho? Ensaio sobre as metamorfoses e a centralidade do mundo do trabalho. 9 ed. São Paulo: Cortez; Campinas: Editora da Unicamp, 2003, p. 26.

58 HOBSBAWM, Eric J. Mundos do trabalho. Trad. Waldea Barcellos e Sandra Bedran. 3. Ed. São Paulo: Paz e Terra, 2000, p. 387-388.
} 
ISSN 1981-3694

(DOI): $10.5902 / 1981369433853$

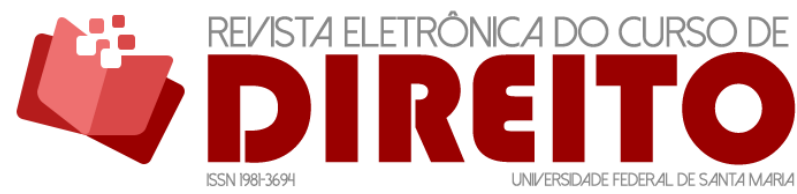

TRABALHO DECENTE SEGUNDO A OIT: UMA CONCEPÇÃO DEMOCRÁTICA? ANÁLISE CRÍTICA À LUZ DA TEORIA DO

CONTRATO SOCIAL

Silvio Beltramelui Neto ISADORA REZENDE BONAMIM JULIA DE CARVALHO VOLTANI

por conseguinte, dos próprios padrões de consumo ${ }^{59}$. A novel feição capitalista, por certo, trouxe a reboque uma nova morfologia da produção fordista, tendo no chamado "modelo japonês" (ou "toyotismo") a iniciativa mais marcante ${ }^{60}$.

A produção toyotista é diversificada e pronta para atender à demanda (sistema "just-intime"), abandonando-se a produção em massa e com isso aproveitando-se melhor o tempo dedicado ao processo produtivo, bem como otimizando-se transporte, controle de qualidade e estoque. No concernente à mão-de-obra, o toyotismo prega a flexibilidade do contrato laboral, inclusive em termos jurídicos, de modo a permitir a disposição da força de trabalho em conformidade com a exigência produtiva do mercado consumidor ${ }^{61}$.

Resulta deste quadro a ampliação da precarização das condições materiais e jurídicas atinentes às relações de trabalho, sobretudo em razão da expansão de formas de subcontratação - v.g. terceirização, trabalho informal, trabalho temporário, trabalho voluntário e cooperativismo -, aliadas à intensificação do tempo de exploração da mão-de-obra sem contraprestação pecuniária direta e satisfatória, a exemplo do banco de horas, dos sistemas

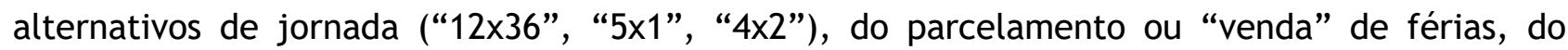
teletrabalho, etc. 0 desemprego estrutural atinge níveis relativamente altos, ampliando-se a redução dos ganhos salariais reais dos ainda empregados e o atroz retrocesso do poder sindical ${ }^{62}$.

O ingresso das práticas toyotistas no Brasil dá-se de forma gradual, identificada por Druck em três etapas. A primeira, na passagem dos anos setenta aos oitenta, com a adoção dos Círculos de Controle de Qualidade (CCQs), em resposta à recessão econômica da época e ao avanço das reivindicações sindicais, insufladas pelo envolvimento na luta pela redemocratização do país. A segunda, em meados da década de oitenta, com a introdução, na indústria automotiva, do just-in-time, dos Programas de Qualidade Total e do Controle Estatístico de Processo. Finalmente, a terceira, já nos anos noventa, com a difusão da "cultura da qualidade total" para todos os setores produtivos de bens e serviços ${ }^{63}$.

\footnotetext{
${ }^{59}$ HARVEY, David. A condição pós-moderna. Trad. Adail Ubirajara Sobral e Maria Stela Gonçalves. 13. ed. São Paulo: Loyola, 2004, p. 140.

${ }^{60}$ ANTUNES, Ricardo. Adeus ao trabalho? Ensaio sobre as metamorfoses e a centralidade do mundo do trabalho. 9 ed. São Paulo: Cortez; Campinas: Editora da Unicamp, 2003, p. 03.

${ }^{61}$ ANTUNES, Ricardo. Adeus ao trabalho? Ensaio sobre as metamorfoses e a centralidade do mundo do trabalho. 9 ed. São Paulo: Cortez; Campinas: Editora da Unicamp, 2003, p. 34 e 36.

62 HARVEY, David. A condição pós-moderna. Trad. Adail Ubirajara Sobral e Maria Stela Gonçalves. 13. ed. São Paulo: Loyola, 2004, p. 141.

63 DRUCK, Graça. Terceirização: (des)fordizando a fábrica. Um estudo do complexo petroquímico. Salvador: EDUPA; São Paulo: Boitempo, 2001, p. 102-103.
} 
ISSN 1981-3694

(DOI): $10.5902 / 1981369433853$

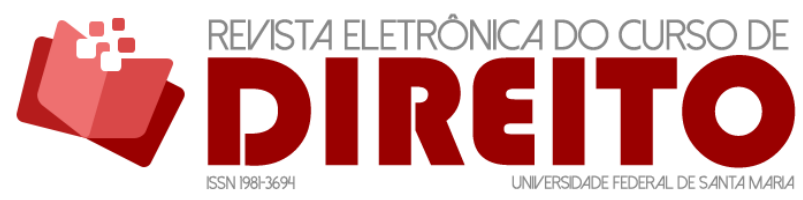

TRABALHO DECENTE SEGUNDO A OIT: UMA CONCEPÇÃO DEMOCRÁTICA? ANÁLISE CRÍTICA À LUZ DA TEORIA DO

CONTRATO SOCIAL

SiLVio BeltrameluI Neto ISADORA REZENDE BONAMIM JULIA DE CARVALHO VOLTANI

Se o capitalismo de acumulação flexível aposta na relação emocional, artificialmente construída, entre consumidor e marca, o mesmo se verifica com o empregado e a marca da empresa em favor da qual despende energia laboral. Daí falar-se em "captura da subjetividade do trabalho vivo", havida com a "apropriação não apenas de habilidades técnico-profissionais da força de trabalho, mas também de disposições subjetivas/anímico volitivas do trabalho vivo em prol da produção de mercadorias" ${ }^{64}$. Como parte deste movimento, há captura da subjetividade dos trabalhadores pela imposição de uma "governança por números [...] agora com uma roupagem tecnológica de última geração"65.

A transformação do capitalismo de acumulação em massa para o capitalismo de acumulação flexível ensejou, pois, intensa transformação no modo de produção, o que implicou profundo enfraquecimento da capacidade de mobilização e reinvindicação obreira, levando sindicatos a sucumbir à lógica capitalista e com ela se conformar, porquanto passam a limitar seus pleitos a aumentos de salários, segurança no emprego e outros benefícios sociais ${ }^{66}$, com isso renunciando à luta por uma alternativa social e distanciando-se daqueles quatro elementos essenciais de orientação social emancipatória do sindicalismo clássico, segundo Hobsbawm.

Todo este panorama coaduna-se com a linha da análise de Boaventura, pois, conquanto negada a politização do espaço da produção, o advento das novas práticas produtivas aprofundou, sobejamente, a influência da dominação do poder econômico na formação da vontade geral dos trabalhadores, a começar, pela captura de sua subjetividade e pela instalação de sistemas de contratação e de produção que mascaram a condição material que une os obreiros enquanto detentores da força de trabalho, mediante a implementação de distinções fáticas e jurídicas (polivalência, terceirização, etc.) que fazem soçobrar a consciência de classe. E a ausência de liberdade na formação da vontade, como visto, macula o propósito do estabelecimento de procedimentos plenamente democráticos, em qualquer instância de decisão.

\footnotetext{
${ }^{64}$ ALVES, Giovanni. A disputa pelo intangível: estratégias gerenciais da capital na era da globalização. In: ANTUNES, Ricardo (Org.). Riqueza e miséria do trabalho no Brasil III. São Paulo: Boitempo, 2014, p. 59. ${ }^{65}$ MELEU, Marcelino da Silva; BANDEIRA, Laís Cristina. A relação laboral na policontexturalidade voltada a uma gorvernança por números e a OIT como organização mediadora. Revista Eletrônica do Curso de Direito da UFSM, Santa Maria, RS, v. 13, n. 1, p. 183-208, abr. 2018, p. 197. ISSN 1981-3694. Disponível em: https://periodicos.ufsm.br/revistadireito/article/view/28239. Acesso em: 12 jul. 2018. doi: http://dx.doi.org/10.5902/1981369428239.

${ }^{66}$ SANTOS, Boaventura de S.; COSTA, Hermes A. Para ampliar o cânone do internacionalismo operário. In: SANTOS, Boaventura de Sousa (Org.). Trabalhar o mundo: os caminhos do novo internacionalismo operário. Rio de Janeiro: Civilização Brasileira, 2005, p. 23; ANTUNES, Ricardo. Adeus ao trabalho? Ensaio sobre as metamorfoses e a centralidade do mundo do trabalho. 9 ed. São Paulo: Cortez; Campinas: Editora da Unicamp, 2003, p. 43.
} 
ISSN 1981-3694

(DOI): 10.5902/1981369433853

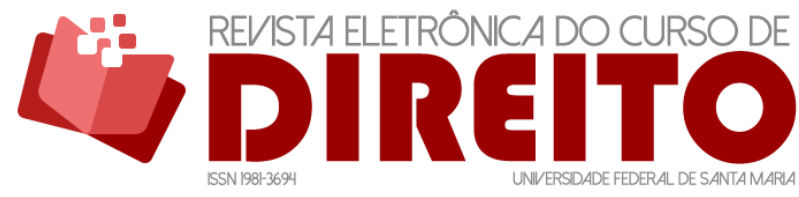

TRABALHO DECENTE SEGUNDO A OIT: UMA CONCEPÇÃO DEMOCRÁTICA? ANÁLISE CRÍTICA À LUZ DA TEORIA DO

CONTRATO SOCIAL

Silvio Beltramelui Neto ISADORA REZENDE BONAMIM JULIA DE CARVALHO VOLTANI

Demais disso, como não poderia deixar de ser, a dissipação da consciência de classe acarreta o distanciamento das pessoas que vivem do seu trabalho das instituições formais de representação, notadamente os sindicatos, circunstância aferível, estatisticamente, a partir da década de oitenta, com a tendência de queda das taxas de sindicalização ${ }^{67}$.

Chega-se, assim, a um quadro em que a negociação empreendida por sindicatos vulneráveis e sem força de reivindicação amparada pela participação política coletiva dos representados legitima precarização de direitos, dentro de um discurso de despolitização das relações laborais. 0 sindicato, neste contexto, deixa de ser, aos olhos da classe trabalhadora, veículo de exercício da democracia representativa ${ }^{68}$, sem, contudo, que o espaço da produção deixe de permanecer, a despeito do discurso reinante, um espaço político por excelência, que, neste momento, não conta com a devida participação ativa por parte da parcela obreira.

É preciso destacar que, a despeito das fragilidades constatadas, os sindicatos não deixam de permanecer protagonistas sobre alternativas superadoras da crise do Contrato Social da modernidade ocidental. Nesta linha, a proposta de Boaventura sobre um "Contrato Social de tipo novo", no qual a inclusão se opera tanto por critérios de igualdade como de diferença (Princípio da Igualdade associado ao Princípio do Reconhecimento das Diferenças), demanda a "redescoberta democrática do trabalho concomitantemente com a reinvenção do movimento sindical" 69 , a se dar na linha do denominado "Novo Sindicalismo Social”, baseado na ampliação das temáticas sindicais, combinando-se com reivindicações de outras naturezas, pertinentes à exclusão social, v.g. pautas relacionadas a gênero, racismo, ecologia, migração, etc ${ }^{70}$.

No que se refere à figura estatal, não é o Estado propriamente que está em crise, mas seu papel original de normalizador das desigualdades incompatíveis com a vontade geral, executado, mais recentemente, através de políticas fiscais e sociais típicas do EstadoProvidência, nos países centrais, e do Estado Desenvolvimentista, nos países semiperiféricos (como o Brasil), até porque, permanecem intactas suas funções repressivas e de liberalização da economia mundial globalizada, com facilitação e proteção das atividades das empresas

\footnotetext{
${ }^{67}$ ANTUNES, Ricardo. Adeus ao trabalho? Ensaio sobre as metamorfoses e a centralidade do mundo do trabalho. 9 ed. São Paulo: Cortez; Campinas: Editora da Unicamp, 2003, p. 67.

68 SANTOS, Boaventura de S. Pela mão de Alice: o social e o político na pós-modernidade. São Paulo: Cortez, 2013, p. 273.

${ }^{69}$ SANTOS, Boaventura de S. A gramática do tempo: para uma nova cultura política. 2. ed. Porto: Edições Afrontamento, 2010, p. 315-316.

70 SANTOS, Boaventura de S.; COSTA, Hermes A. Para ampliar o cânone do internacionalismo operário. In: SANTOS, Boaventura de Sousa (Org.). Trabalhar o mundo: os caminhos do novo internacionalismo operário. Rio de Janeiro: Civilização Brasileira, 2005, p. 42.
} 
ISSN 1981-3694

(DOI): $10.5902 / 1981369433853$

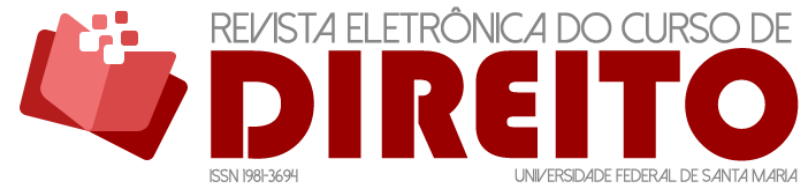

TRABALHO DECENTE SEGUNDO A OIT: UMA CONCEPÇÃO DEMOCRÁTICA? ANÁLISE CRÍTICA À LUZ DA TEORIA DO

CONTRATO SOCIAL

SiLVio Beltramelui Neto

ISADORA REZENDE BONAMIM

JULIA DE CARVALHO VOLTANI

privadas $^{71}$. O Estado, cooptado pelo capital internacional, por um lado, se enfraquece enquanto agente de solução de desigualdades - em dissonância com a lógica do Contrato Social -, mas, por outro, se fortalece como detentor da prerrogativa de abrir caminhos para o liberalismo econômico, com limitação das exigências de caráter trabalhista ${ }^{72}$. É neste horizonte, portanto, que a democracia representativa debilita-se como ferramenta em prol da inclusão social, podendo-se cogitar da reversão deste quadro apenas na hipótese de avanço da democracia participativa orientada à redistribuição ${ }^{73}$.

Em assim sendo, o rompimento do Contrato Social pela fragmentação da sociedade desigual e excludente abala, vigorosamente, toda a sustentação da democracia representativa, na perspectiva da conjugação dos conceitos de vontade geral, Soberano e Governo.

$\mathrm{Na}$ linha do exposto, em sendo conduzida por deliberações de Estados e de entidades de representação obreira e patronal, todos influenciados pelo contexto da crise do Contrato Social, não poderia a OIT estar, como de fato não está, infensa aos problemas de déficit da democracia representativa nos espaços mundial e da produção. Daí que à concepção de Trabalho Decente não se deva conferir a pecha de democrática, apenas porque adotada na seara de uma organização internacional tripartite.

Entretanto, na esteira da percepção de Boaventura sobre o capitalismo, não cabe tachar o procedimento de construção da concepção de Trabalho Decente de antidemocrático, mas afigura-se absolutamente plausível cogitá-lo não suficientemente democrático, ao menos na perspectiva da plenitude da contemplação da vontade geral. Tal percepção, diga-se, conquanto não encampe o Trabalho Decente como meio de construção do "Contrato Social de tipo novo", não menospreza o potencial que certos aspectos seus apresentam no sentido de mitigar a exclusão social verificada no âmbito das relações de trabalho capitalistas neoliberais, sobretudo no que tange à mediação de consensos, ainda que dependentes de implementação, acerca de

\footnotetext{
71 SANTOS, Boaventura de S. A gramática do tempo: para uma nova cultura política. 2. ed. Porto: Edições Afrontamento, 2010, p. 328.

72 SANTOS, Boaventura de S.; COSTA, Hermes A. Para ampliar o cânone do internacionalismo operário. In: SANTOS, Boaventura de Sousa (Org.). Trabalhar o mundo: os caminhos do novo internacionalismo operário. Rio de Janeiro: Civilização Brasileira, 2005, p. 34.

73 "A democracia representativa só fracassa porque é corrupta e porque se recusa a aceitar os desafios da democracia participativa" (SANTOS, Boaventura de S. Poderá o direito ser emancipatório? Revista Crítica de Ciências Sociais, n. 65, p. 03-76, 2003, p. 31). "Numa esfera pública em que o Estado incorpora interesses e organizações não-estatais cujos actos ele próprio coordena, a democracia redistributiva não pode restringir-se à democracia representativa, uma vez que esta foi concebida para a acção política convencional, o que equivale a dizer que se acha confinada ao domínio estatal" (SANTOS, Boaventura de S. Poderá o direito ser emancipatório? Revista Crítica de Ciências Sociais, n. 65, p. 03-76, 2003, p. 65).
} 
ISSN 1981-3694

(DOI): $10.5902 / 1981369433853$

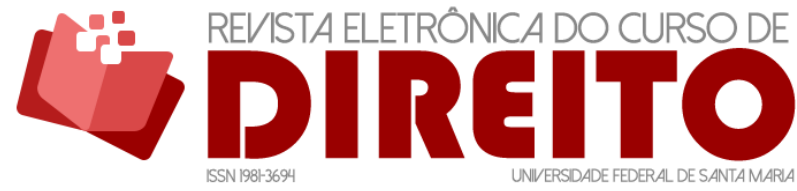

TRABALHO DECENTE SEGUNDO A OIT: UMA CONCEPÇÃO DEMOCRÁTICA? ANÁLISE CRÍTICA À LUZ DA TEORIA DO

CONTRATO SOCIAL

Silvio Beltramelui Neto

ISADORA REZENDE BONAMIM

JULIA DE CARVALHO VOLTANI

um padrão global mínimo de direitos dos trabalhadores, o que se percebe da enunciação da promoção dos direitos e princípios do trabalho consagrados pela Declaração da OIT sobre Princípios e Direitos Fundamentais no Trabalho de 1998 como um dos quatro objetivos do Trabalho Decente.

Esta conclusão, direcionada ao horizonte global e ampliado da OIT, confirma-se, como se pretende demonstrar adiante, à abordagem do Trabalho Decente pelo Estado brasileiro, em especial no que tange à Agenda Nacional de Trabalho Decente.

\section{AGENDA NACIONAL DE TRABALHO DECENTE: DIÁLOGO SOCIAL DEMOCRÁTICO ${ }^{74}$}

No campo prático, o Trabalho Decente ganha concretude quando a OIT propõe aos Estados Membros uma cooperação técnica visando a criação de programas personalizados, conforme os valores, as necessidades e as possibilidades de cada região ${ }^{75}$. Trata-se das "Agendas de Trabalho Decente", que se destinam ao desenvolvimento de ações que busquem concretizar os quatro objetivos estratégicos apresentados pela $\mathrm{OIT}^{76}$. Neste compasso, as agendas são documentos que, em tese, traçam um diagnóstico do local em questão para posterior assentamento das prioridades locais, eixos prioritários, metas e formas de monitoramento. A implementação do Trabalho Decente, revela-se, assim, uma estratégia baseada em uma noção internacionalmente construída, mas, em boa medida, nacionalmente implementada.

À semelhança dos moldes deliberativos da OIT, as agendas são estruturadas no formato tripartite, figurando o diálogo social como um eixo transversal nas atividades anteriores e posteriores aos programas estabelecidos.

A “Agenda Nacional de Trabalho Decente” brasileira (ANTD) foi lançada em 2006, com a definição dos seguintes eixos prioritários: gerar mais e melhores empregos, com igualdade de oportunidades e de tratamento; erradicar o trabalho escravo e eliminar o trabalho infantil, em

\footnotetext{
${ }^{74}$ Relembre-se que este tópico, fiel ao objeto da análise, não põe à prova a pertinência do conteúdo das linhas de ação e medidas propostas pela Agenda Nacional de Trabalho Decente, senão apenas o que efetivamente disser respeito ao processo de sua construção, a fim de perquirir sobre sua natureza democrática.

${ }^{75}$ ABRAMO, Laís. Trabalho Decente: o itinerário de uma proposta. Bahia Análise \& Dados, Salvador, v. 20, n. 2/3, p. 151-171, jul./set. 2010, p. 153.

76 OIT. Uma década de trabalho decente no Brasil: uma estratégia de ação baseada no diálogo social. Genebra: OIT, 2015, p. 45. Disponível em: http://www.ilo.org/wcmsp5/groups/public/---americas/---rolima/---ilo-brasilia/documents/publication/wcms_467352.pdf. Acesso em: 12 jul. 2018.
} 
ISSN 1981-3694

(DOI): $10.5902 / 1981369433853$

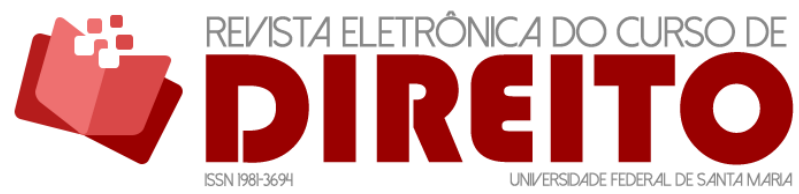

TRABALHO DECENTE SEGUNDO A OIT: UMA CONCEPÇÃO DEMOCRÁTICA? ANÁLISE CRÍTICA À LUZ DA TEORIA DO

CONTRATO SOCIAL

Silvio Beltramelli Neto

ISADORA REZENDE BONAMIM

JULIA DE CARVALHO VOLTANI

especial em suas piores formas; e fortalecer os atores tripartites e o diálogo social como um instrumento de governabilidade democrática ${ }^{77}$.

Estruturalmente, a ANTD não reserva espaço minudente à descrição do processo a que se constituiu, dificultando a perquirição acerca do grau de diálogo social envidado. Embora esclareça que seu planejamento foi discutido em conferências e reuniões internacionais realizadas entre 2003 e $2005^{78}$, no que tange os atores sociais participantes da sua construção, a Agenda limita-se a referir-se a um Comitê Executivo composto por órgãos do à época intitulado Ministério do Trabalho e Emprego (MTE), responsável pela "formulação de projetos nas áreas prioritárias de cooperação, bem como a tarefa de mobilizar os recursos técnicos e financeiros necessários para a implementação, o monitoramento e avaliação desses projetos"79.

Em 2005, o afinco orientado à construção da ANTD voltou-se ao esboço de uma proposta no âmbito de grupos técnicos compostos por secretarias e departamentos do MTE. Posteriormente, o projeto foi submetido à discussão no denominado Grupo Interministerial (GI) ${ }^{80}$ e à consulta na Comissão Tripartite de Relações Internacionais (CTRI) ${ }^{81}$. A Comissão Tripartite foi instituída em observância à Convenção n 144 da OIT sobre Consultas Tripartites sobre Normas Internacionais do Trabalho, materializada por meio da Portaria MTE $n .^{\circ} 447$, de 19 de agosto de 2004, a qual nomeou os integrantes da Comissão e delimitou suas competências ${ }^{82}$.

Segundo o texto normativo da Portaria n. ${ }^{\circ}$ 447, integram a CTRI: o governo, representado por quadros do MTE, bem como Confederação da Agricultura e Pecuária do Brasil

77 BRASIL. Ministério do Trabalho e Emprego. Agenda Nacional do Trabalho Decente. Brasília: Ministério do Trabalho e Emprego, 2006, p. 9-10. Disponível em: http://www.ilo.org/wcmsp5/groups/public/--americas/---ro-lima/---ilo-brasilia/documents/publication/wcms_226229.pdf. Acesso em: 12 jul. 2018.

78 Das conferências e reuniões, tomam-se como exemplo os seguintes eventos: Conferência Regional de Emprego do Mercosul, XIII e WVI Conferências Interamericanas de Ministros do Trabalho da Organização dos Estados Americanos (OEA), Assembleia Geral das Nações Unidas (ONU) e IV Cúpula das Américas ( ${ }^{78}$ BRASIL. Ministério do Trabalho e Emprego. Agenda Nacional do Trabalho Decente. Brasília: Ministério do Trabalho e Emprego, 2006, p. 5-6).

7979 BRASIL. Ministério do Trabalho e Emprego. Agenda Nacional do Trabalho Decente. Brasília: Ministério do Trabalho e Emprego, 2006, p. 08.

80 O Grupo Interministerial contou com a participação de ministérios e secretarias do Governo Federal, quais sejam: Trabalho e Emprego, Relações Exteriores, Desenvolvimento Social e Combate à Fome, Previdência Social, Justiça, Educação, Saúde, Direitos Humanos, Políticas para as mulheres, Promoção da igualdade Racial e Relações Institucionais (OIT. Uma década de trabalho decente no Brasil: uma estratégia de ação baseada no diálogo social. Genebra: OIT, 2015, p. 62. Disponível em: http://www.ilo.org/wcmsp5/groups/public/---americas/---ro-lima/---ilobrasilia/documents/publication/wcms_467352.pdf. Acesso em: 12 jul. 2018.).

81 OIT. Uma década de trabalho decente no Brasil: uma estratégia de ação baseada no diálogo social. Genebra: OIT, 2015, p. 60. Disponível em: http://www.ilo.org/wcmsp5/groups/public/---americas/---rolima/---ilo-brasilia/documents/publication/wcms_467352.pdf. Acesso em: 12 jul. 2018.

82 BRASIL. Ministério do Trabalho e Emprego. Portaria MTE n. ${ }^{\circ} 447$, de 19 de agosto de 2004. In: Diário Oficial da União, Brasília, DF, 20 ago. 2004. Disponível em: https: // www.legisweb.com.br/legislacao/?id=188173. Acesso em: 12 jul. 2018. 
ISSN 1981-3694

(DOI): $10.5902 / 1981369433853$

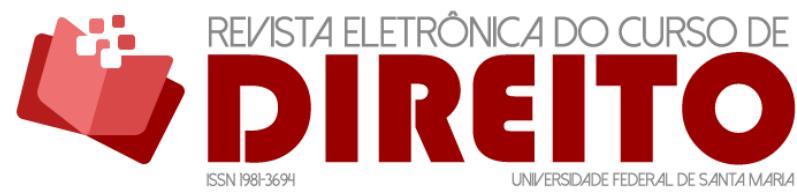

TRABALHO DECENTE SEGUNDO A OIT: UMA CONCEPÇÃO DEMOCRÁTICA? ANÁLISE CRÍTICA À LUZ DA TEORIA DO

CONTRATO SOCIAL

Silvio Beltramelui Neto

ISADORA REZENDE BONAMIM

JULIA DE CARVALHO VolTANI

(CNA), Confederação Nacional do Comércio (CNC), Confederação Nacional da Indústria (CNI), Confederação Nacional das Instituições Financeiras (CNF), Confederação Nacional do Transporte (CNT), Central Única dos Trabalhadores (CUT), Confederação Geral dos Trabalhadores (CGT), Força Sindical (FS), Central Autônoma de Trabalhadores (CAT), Central Geral dos Trabalhadores do Brasil (CGTB), e Social Democracia Sindical (SDS).

Quanto à competência, designou-se à CTRI a análise das agendas de trabalho propostas por fóruns internacionais e a pronúncia sobre assuntos que eventualmente sejam-lhes submetidos pelo Ministro de Estado do Trabalho e Emprego ${ }^{83}$.

Do ponto de vista institucional, uma reflexão sobre o caráter democrático do arranjo que resultou na ANTD reclama, pois, o exame da representatividade dos grupos escolhidos para compor a CTRI, a exigir, por sua vez, a contextualização histórica e normativa do sistema sindical brasileiro, dentro do qual se colocam as agremiações integrantes daquela Comissão.

As primeiras formas associativas brasileiras de trabalhadores são constatadas ao final do século XIX, com atuação de perfil mais assistencialista do que reivindicatória, em que pese a proibição pela então vigente Constituição de 1824 das chamadas corporações de ofício ${ }^{84}$.

Já no início do século XX, concomitantemente com o surto industrial do país, acarretador da concentração populacional na região sudeste do território, o movimento operário, integrado basicamente por trabalhadores estrangeiros e oriundos da área rural, conquanto ainda carente de reconhecimento legal e confrontado pela violência estatal, vê-se impulsionado por reivindicações conduzidas por intensos movimentos grevistas ${ }^{85}$. As associações operárias adquiriram o nome de "sindicato", em 06 de janeiro de 1903, com a promulgação do Decreto 979, que autorizou a reunião de profissionais da agricultura e indústria para a defesa de seus interesses, ao que se sucederam importantes normas que inauguraram a regulação estrutural da organização sindical brasileira, sendo a primeira delas o artigo 72 da Constituição de 1891, que previu o direito de livre associação, seguida dos Decreto 979/1903 e 1.637/1907, que dispuseram sobre a permissão de criação de sindicatos e, posteriormente, a Constituição de 1934, que marcou o estabelecimento da fase de pluralismo e autonomia sindical.

Os anos trinta vão notabilizar a consolidação do reconhecimento jurídico de um movimento operário já não tanto marcado pela presença estrangeira, reconhecimento tal,

\footnotetext{
${ }^{83}$ BRASIL. Ministério do Trabalho e Emprego. Portaria MTE n. ${ }^{\circ} 447$, de 19 de agosto de 2004, cit.

${ }^{84}$ MISAILIDIS, Mirta L. Os desafios do sindicalismo brasileiro diante das atuais tendências. São Paulo: LTr, 2001, p. 43-44.

${ }^{85}$ MISAILIDIS, Mirta L. Os desafios do sindicalismo brasileiro diante das atuais tendências. São Paulo: LTr, 2001, p. 45-49.
} 
ISSN 1981-3694

(DOI): $10.5902 / 1981369433853$

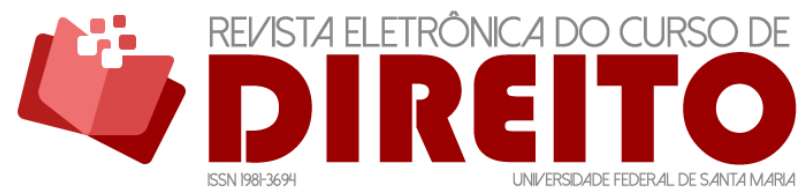

TRABALHO DECENTE SEGUNDO A OIT: UMA CONCEPÇÃO DEMOCRÁTICA? ANÁLISE CRÍTICA À LUZ DA TEORIA DO

CONTRATO SOCIAL

Silvio Beltramelui Neto ISADORA REZENDE BONAMIM JULIA DE CARVALHO VOLTANI

porém, que se aufere sob controle rigoroso do Estado. 0 período pós anos trinta marca, então, a incorporação da classe trabalhadora ao cenário político nacional, no papel de ator central ${ }^{86}$.

Com a promulgação da Constituição de 1937 e do Decreto 1.402/1939, a pluralidade sindical cede lugar à unicidade, modelo esse consagrado, depois, com a edição da CLT, em 1943, e que se perpetuou até os dias atuais, a ponto de ser reproduzido pelo art. $8^{\circ}$ da Constituição Federal de 1988. Segundo tal modelo, é permitida a existência de apenas um sindicato patronal ou profissional para cada categoria, em uma mesma base territorial não inferior a um município.

Em meio ao declínio do regime ditatorial militar instaurado no país, em 1964, os anos oitenta veem a emergência do chamado "novo sindicalismo" como resposta à crise econômica mundial e nacional dos anos setenta, à financeirização do capital e ao avanço tecnológico nos processos produtivos já fragmentados pelas práticas toyotistas, associados à incapacidade do Estado de prover serviços públicos com qualidade. Contextualizada pelo clamor democrático que se intensificava e dele se valendo, a mobilização operária, muitas vezes à margem dos sindicatos oficiais controlados pelo Estado, renova-se em inúmeras e importantes greves do funcionalismo público e do setor industrial, sempre tendo por principal pleito a autonomia sindical em face do Estado $^{87}$, a ser conquistada com a Constituição Federal de 1988.

O "novo sindicalismo", todavia, se arrefeceria às portas da década de noventa, sucumbindo à reestruturação produtiva impingida em escala global e à emergência da pragmática neoliberal e da financeirização do capital, passando de um sindicalismo de confronto (contestador) para o sindicalismo negocial (conciliador), onde o embate cede espaço para estratégias de parceria, negociação e incentivo aos pactos sindicais ${ }^{88}$.

Com a nova Carta Constitucional, os sindicatos brasileiros deixam de depender de autorização estatal para sua criação, contudo, seus atos constitutivos livremente redigidos devem ser submetidos ao Ministério do Trabalho, para fins de registro e apuração da observância da unicidade territorial, mantida tal qual estatuída na CLT (art. $8^{\circ}$, I, III e VIII da Constituição

\footnotetext{
${ }^{86}$ FRANÇA, Carlos Eduardo; CABRAL, Rafael L. Direitos sociais e identidade operária: o poder da ideologia trabalhista no governo de Getúlio Vargas (Brasil, 1930-45). Revista Eletrônica do Curso de Direito da UFSM, Santa Maria, RS, v. 13, n. 1, p. 1-19, abr. 2018, p. 641. ISSN 1981-3694. Disponível em: https://periodicos.ufsm.br/revistadireito/article/view/21961/pdf. Acesso em: 12. jul. 2018. doi: http://dx.doi.org/10.5902/1981369421961.

87 MISAILIDIS, Mirta L. Os desafios do sindicalismo brasileiro diante das atuais tendências. São Paulo: LTr, 2001, p. 72-75.

${ }^{88}$ ANTUNES, Ricardo; SILVA, Jair Batista da. Para onde foram os sindicatos? Do sindicalismo de confronto ao sindicalismo negocial. Caderno CRH, Salvador, v. 28, n. 75, p. 511-527, Dez/2015, p. 511-512; SANTOS, Boaventura de S.; SANTOS, Boaventura de S. A gramática do tempo: para uma nova cultura política. 2. ed. Porto: Edições Afrontamento, 2010, p. 362.
} 
ISSN 1981-3694

(DOI): 10.5902/1981369433853

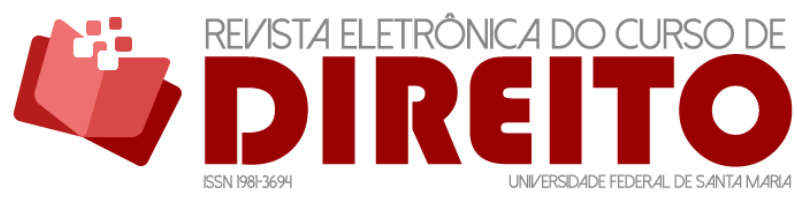

TRABALHO DECENTE SEGUNDO A OIT: UMA CONCEPÇÃO DEMOCRÁTICA? ANÁLISE CRÍTICA À LUZ DA TEORIA DO

CONTRATO SOCIAL

Silvio Beltramelui Neto

ISADORA REZENDE BONAMIM

JULIA DE CARVALHO VOLTANI

Federal), conquanto incompatível com a plena liberdade sindical consagrada pelo o artigo $2^{\circ}$ da Convenção $n^{\circ} 87$ da OIT, não ratificada, bem por isso, pelo Brasil.

o panorama normativo brasileiro atual reconhece, portanto, os sindicatos como associações, as quais têm a função de representar trabalhadores vinculados através de laços profissionais comuns, visando tratar de problemas coletivos das respectivas bases representadas, defendendo seus interesses, com o objetivo de auferir melhores condições de vida e labor.

A lei brasileira não admite, no entanto, mais de um sindicato representativo da mesma categoria em uma dada base territorial (art. $8^{\circ}$, II, da Constituição Federal e art. 516 da CLT), embora o sindicato possa ter uma base territorial de extensão distrital, municipal, intermunicipal, estadual e interestadual, sendo que, excepcionalmente, e atendendo às peculiaridades de determinadas categorias ou profissões, o Poder Executivo, através do Ministério do Trabalho, poderá autorizar o reconhecimento de sindicatos com base territorial nacional (art. 517 da CLT). 0 desmembramento de um sindicato é admitido (art. 571 da CLT).

0 agrupamento sindical, no Brasil, portanto, submete-se a critérios rígidos: apenas um sindicato por categoria profissional ou patronal e por base territorial. 0 enquadramento sindical por categorias, associado à unicidade, gera problemas sérios de participação política e de representatividade, pois impossibilita que os trabalhadores escolham, livremente, as associações sindicais à quais queiram se vincular. Há, por conseguinte, um problema democrático.

Ademais, o sistema sindical brasileiro não se resume aos sindicatos, sendo confederativo, por apresentar diferentes graus de associações sindicais, segundo a lei. Pela ordem crescente desses graus tem-se os sindicatos propriamente ditos ( $\left.1^{\circ} \mathrm{grau}\right)$, as federações ( $2^{\circ}$ grau) e as confederações ( $3^{\circ}$ grau). As federações são organizadas por Estados da Federação, a partir da reunião de um número não inferior a cinco sindicatos, desde que representem a maioria absoluta de um grupo de atividades ou profissões idênticas, similares ou conexas (art. 534 da CLT). Já as confederações são entidades de abrangência nacional, com sede na capital do país e constituídas pelo agrupamento mínimo de três federações (art. 535 da CLT).

Eis a grande questão: as centrais sindicais - únicas integrantes da CRTI e participantes da construção da ANTD como representantes obreiras - em tese, estão fora desse sistema confederativo, embora, de fato, articulem-se e atuem a partir dele, desde a década de 60, na mobilização política e reivindicatória de diversas categorias profissionais. Não obstante, seu reconhecimento jurídico deu-se tão somente pela posterior aprovação da Lei 11.648, de 31 de março de 2008. Desvencilhadas da unicidade que vincula os três graus associativos sindicais brasileiros, as centrais estão legalmente autorizadas a coordenar a representação dos 
ISSN 1981-3694

(DOI): $10.5902 / 1981369433853$

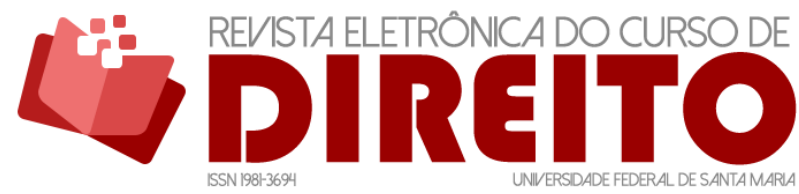

TRABALHO DECENTE SEGUNDO A OIT: UMA CONCEPÇÃO DEMOCRÁTICA? ANÁLISE CRÍTICA À LUZ DA TEORIA DO

CONTRATO SOCIAL

Silvio Beltramelui Neto ISADORA REZENDE BONAMIM JULIA DE CARVALHO VOLTANI

trabalhadores por meio das organizações sindicais a ela filiadas e a participar de negociações em fóruns, colegiados de órgãos públicos e demais espaços de diálogo social que possuam composição tripartite, nos quais estejam em discussão assuntos de interesse geral dos trabalhadores (art. $1^{\circ}$ da Lei 11.648/08). Entretanto, às centrais é negada a prerrogativa de estabelecer acordos coletivos de trabalho e convenções coletivas de trabalho, atos privativos dos sindicatos, das federações e das confederações, sucessivamente, tal qual o é a greve. A situação relativa à inclusão formal das centrais sindicais no sistema sindical brasileiro não seria, todavia, um problema em termos democráticos se essas instituições tivessem a si adjudicada, de fato, a prerrogativa da representatividade da vontade geral obreira. Não é, porém, o que se vê.

Um olhar para a atuação hodierna do sistema sindical brasileiro revela ausência de unicidade de discurso, descortinada com marcante clareza no âmbito das próprias centrais sindicais, do que são exemplos eloquentes as divergências em relação à alteração recente da legislação brasileira, pela via da aprovação da Lei 13.429/2017, autorizadora de enorme ampliação das hipóteses de terceirização de mão-de-obra. Esta nova regulamentação intensifica o cumprimento da agenda neoliberal para as relações de trabalho pelo Brasil e incentiva a contratação triangular, permitindo que se cogite a forte ampliação do atual quadro de mais de 12 milhões de pessoas sujeitas a um regime de trabalho precarizado, porquanto deficitário, como já estatisticamente demonstrado, em termos de longevidade contratual, remuneração, limitação de jornada laboral e de riscos à saúde e segurança ${ }^{89}$. Há, portanto, implementação de medidas tendentes a aprofundar a exclusão social que abalroa a vontade geral solidarista e afronta o Contrato Social.

Apesar da gravidade do novo panorama normativo, o movimento sindical brasileiro não logrou consenso sobre os limites da terceirização, sendo possível encontrar desde posições radicalmente contrárias até posições favoráveis entusiastas - sobretudo das agremiações cuja existência depende justamente da massa obreira terceirizada, como os sindicatos de

${ }^{89}$ CENTRAL ÚNICA DOS TRABALHADORES. Terceirização e Desenvolvimento: uma conta que não fecha Dossiê acerca do impacto da Terceirização sobre os trabalhadores e propostas para garantir a igualdade de direitos. São Paulo: Central Única dos Trabalhadores, 2014. Disponível em: https://www.cut.org.br/system/uploads/ck/files/Dossie-Terceirizacao-e-Desenvolvimento.pdf. Acesso em: 12 jul. 2018; DIEESE. Nota técnica $\mathrm{n}^{\circ}$ 172: terceirização e precarização das condições de trabalho Condições de trabalho e remuneração em atividades tipicamente terceirizadas e contratantes. São Paulo: DIEESE, 2017. Disponível

em: https://www.dieese.org.br/notatecnica/2017/notaTec172Terceirizacao.html. Acesso em 12 jul. 2018; Idem. Nota Técnica ${ }^{\circ}$ 175: Impactos da lei 13.429/17 (antigo PL 4.302/1998) para os trabalhadores. São Paulo: DIEESE, 2017. Disponível em: https://www.dieese.org.br/notatecnica/2017/notaTec175TerceirizacaoTrabalhoTemporario.html. Acesso em 12 jul. 2018 . 
ISSN 1981-3694

(DOI): $10.5902 / 1981369433853$

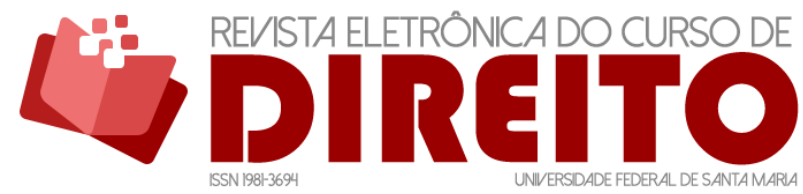

TRABALHO DECENTE SEGUNDO A OIT: UMA CONCEPÇÃO DEMOCRÁTICA? ANÁLISE CRÍTICA À LUZ DA TEORIA DO

CONTRATO SOCIAL

SiLVio BeltrameluI Neto ISADORA REZENDE BONAMIM JULIA DE CARVALHO VOLTANI

trabalhadores terceirizados -, passando por entendimentos mitigados, v.g. a defesa da pertinência da terceirização de atividades-meio ${ }^{90}$. Aliás, nem mesmo uma ação robusta contra a Lei da Reforma Trabalhista (Lei $n^{\circ} 13.467 / 2017$ ) foi engendrada pelas centrais, a despeito do óbvio retrocesso impingido à proteção jurídica de todo o tipo de trabalhador ${ }^{91}$.

O déficit de participação política formal dos representados junto aos sindicatos também é um dado relevante para a análise em curso. Os setores mais suscetíveis à terceirização apresentam menores índices de sindicalização, se comparados aos setores mais estruturados e afeitos à contratação direta. Exemplificativamente e com base em dados de 2015, de um lado, os setores da construção civil e do comércio, marcadamente partidários da delegação de atividades, contam com índices de sindicalização de 9,3\% e 13,3\%, respectivamente; de outro lado, os ramos agrícola e da indústria de transformação, menos afeitos à terceirização, ostentam índices substancialmente superiores de $28,7 \%$ e $23,3 \%$, respectivamente. Considerando-se a média nacional global de sindicalizados de 19,5\%, evidencia-se a quão deficitária é a sindicalização dos terceirizados, em um país no qual o ato de se sindicalizar já é, em geral, pouco frequente ${ }^{92}$.

No que se refere às negociações coletivas, é certo que quanto mais sujeita à precarização das condições de trabalho é a categoria, menos mobilização sindical há e menos conquistas se concretizam em acordos ou convenções coletivas de trabalho. Para se ter uma ideia, justamente os setores mais precários em termos de condições de trabalho ostentam pouca ou nenhuma previsão, em acordo ou convenção coletiva de trabalho, sobre saúde e segurança ${ }^{93}$.

Não se pode, ademais, descartar a hipótese de um sensível distanciamento físico e discursivo entre as figuras que personificam o movimento sindical e os trabalhadores representados, situação imersa na própria dissonância de pautas das entidades sindicais. A

90 GALVÃO, Andréia; TEIXEIRA, Marilane O. Flexibilização na lei e na prática: o impacto da reforma trabalhista sobre o movimento sindical. In: KREIN, José Dari; GIMENEZ, Denis M.; SANTOS, Anselmo L. (Coord.). Dimensões críticas da reforma trabalhista no Brasil. Campinas/SP: Curt Nimuendajú, 2018, p. 175-176.

91 GALVÃO, Andréia; TEIXEIRA, Marilane O. Flexibilização na lei e na prática: o impacto da reforma trabalhista sobre o movimento sindical. In: KREIN, José Dari; GIMENEZ, Denis M.; SANTOS, Anselmo L. (Coord.). Dimensões críticas da reforma trabalhista no Brasil. Campinas/SP: Curt Nimuendajú, 2018, p. 171.

92 IBGE. Aspectos das Relações de Trabalho e Sindicalização. IBGE: Rio de Janeiro, 2017, p. 51-54.

${ }_{93}$ GALVÃO, Andréia; TEIXEIRA, Marilane O., op. cit., p. 167. Nesse ponto, José Cláudio Filho ao analisar contratos coletivos realizados com a participação de sindicatos profissionais brasileiros, concluiu que o máximo se tem conseguido é manter os direitos e garantias já conquistados anteriormente, sem grandes avanços pelo menos nos últimos quinze anos (BRITO FILHO, José Claudio Monteiro de. A dimensão coletiva dos direitos sociais trabalhistas na perspectiva sindical. In: DELGADO, Gabriela Neves; PEREIRA, Ricardo José Macêdo De Britto (Org.). Trabalho, constituição e cidadania: a dimensão coletiva dos direitos sociais trabalhistas. São Paulo: Ltr, 2014. p. 251-257, p. 256). 
ISSN 1981-3694

(DOI): $10.5902 / 1981369433853$

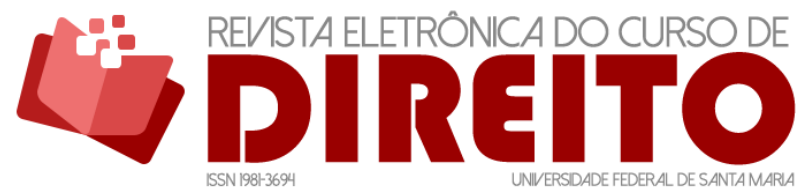

TRABALHO DECENTE SEGUNDO A OIT: UMA CONCEPÇÃO DEMOCRÁTICA? ANÁLISE CRÍTICA À LUZ DA TEORIA DO

CONTRATO SOCIAL

Silvio Beltramelui Neto ISADORA REZENDE BONAMIM JULIA DE CARVALHO VOLTANI

respeito, Young ${ }^{94}$, partindo do ponto de vista da representação não configurar uma substituição ou identificação dos indivíduos, destaca a necessidade de o representante permear as relações sociais do grupo representado, a fim de se permitir que as experiências e percepções do representante proveja as de uma pessoa posicionada na mesma situação dos representados ${ }^{95}$, fazendo lembrar a relação entre cidadão e governo, à feição rousseauniana. Tais conjecturas, no entanto, desvelam a proeminência da lógica da prevalência dos interesses particulares sobre a vontade geral, que sequer pode ser vislumbrada, no quadro que se apresenta.

Mas não é só. As ponderações, até o momento, circunscreveram-se aos trabalhadores formais, os quais, ao menos, valem-se de uma estrutura sindical formal de representação, a despeito da crise de representatividade. Mais grave, porém, é a realidade dos trabalhadores informais, olvidados por completo no diálogo social de construção da ANTD, dada a ausência de representação formal na CTRI. Dados oficiais do IBGE, em dezembro de 2017, revelam que o Brasil contava com 92,1 milhões de brasileiros ocupados, dos quais expressivos $37,1 \%$ ou 34,2 milhões são considerados trabalhadores informais (sem carteira de trabalho assinada ou laborando por conta própria) ${ }^{96}$.

Nessa perspectiva, Trebilcock alerta que o real desafio em torno do diálogo social tripartite recai justamente na representatividade em relação às pessoas que se afastam das organizações envolvidas, como os trabalhadores fora da economia formal ou setor dos trabalhadores que não estão organizados em sindicatos ${ }^{97}$. Eis, pois, mais uma circunstância de evidente exclusão, impeditiva do reconhecimento da atividade sindical brasileira como democrática, na acepção delineada pelo Contrato Social. Trata-se de uma observação absolutamente atinente ao processo de elaboração da ANTD.

Tem-se, assim, que o sistema sindical brasileiro consolida um modelo marcado, formalmente, pela unicidade sindical, pela compulsoriedade de representação e pela indiferença com os trabalhadores informais, e, socialmente, pela pouca participação política de trabalhadores e frágil capacidade de mobilização das bases entre si, no que respeita às pautas comuns. Tais características impedem possa ser este modelo classificado como plenamente democrático, principalmente à luz dos marcos clássico e contemporâneo, de Rousseau e

\footnotetext{
${ }^{94}$ YOUNG, Iris Marion. Representação política, identidade e minorias. Lua Nova, São Paulo, n. 67, p.139190, 2006, p. 142.

95 YOUNG, Iris Marion. Representação política, identidade e minorias. Lua Nova, São Paulo, n. 67, p.139190, 2006, p. 179.

96 IBGE. Pesquisa Nacional por Amostra de Domicílios Contínua: outubro a dezembro de 2017. Brasília: IBGE, 2018. Disponível em: <https://goo.gl/6FvmZF>. Acesso em: 30 abr. 2018.

97 TREBILCOCK, Anne. Towards social dialogue: Tripartite cooperation in national economic and social policy-making. Ginebra: OIT, 1994, p. 09.
} 
ISSN 1981-3694

(DOI): $10.5902 / 1981369433853$

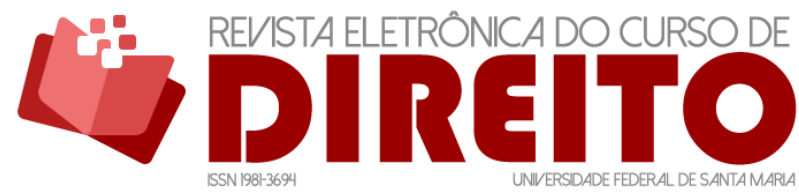

TRABALHO DECENTE SEGUNDO A OIT: UMA CONCEPÇÃO DEMOCRÁTICA? ANÁLISE CRÍTICA À LUZ DA TEORIA DO

CONTRATO SOCIAL

Silvio Beltramelui Neto ISADORA REZENDE BONAMIM JULIA DE CARVALHO VOLTANI

Boaventura, referenciados neste estudo, notadamente em razão de seu traço excludente. Isto não significa que as entidades sindicais não cumpram um papel fundamental para a democracia brasileira, tal como para o "Contrato Social de tipo novo", conforme já esclarecido, anteriormente. Está-se, enfim, diante de um sistema (o sindical brasileiro) que não é antidemocrático, embora seja não suficientemente democrático, sob a ótica da noção rousseauniana de vontade geral - conclusão similar à imputada ao procedimento de adoção da concepção de Trabalho Decente pela OIT.

Do ponto de vista de um processo deliberativo, um segundo problema, além da representatividade dos participantes, verificado na construção da ANTD, foi a eleição da "consulta" como modalidade de diálogo social praticada ${ }^{98}$. Depreende-se do que consta dos documentos franqueados ao conhecimento público que a ANTD e seu desdobramento imediato, o Plano Nacional de Trabalho Decente (PNTD), foram precedidos de debates convocados pelo governo, no âmbito da CTRI, sem que, contudo, tenham as entidades sindicais obreiras e patronais participado, com poder de decisão, do processo deliberativo. Está-se a falar de documentos cujos conteúdos são, ao cabo, definidos exclusivamente pelo governo, afigurando-se mais uma circunstância que impede que o iter de construção da ANTD e de seus desdobramentos possa ser classificado como amplamente democrático. O que parece existir, pois, é uma concentração deliberativa nas mãos do Estado e a participação dos atores sociais como organismos pareceristas, o que se revela na contramão da própria estrutura da OIT $^{99}$.

A contradição também se manifesta quando um dos eixos prioritários da ANTD repousa no fortalecimento dos atores tripartites e o diálogo social como um instrumento de governabilidade democrática, enquanto os próprios atores não dispuseram do poder de deliberação na construção da Agenda.

À vista deste conjunto de problemas de representatividade sindical e de diálogo social especialmente mitigado, afigura-se absolutamente plausível e aplicável ao caso brasileiro a percepção de Diaz, segundo a qual não é o diálogo social que está em crise, posto se tratar de um instrumento liberal de equalização de interesses de exercício habitual na democracia (por

BRASIL. Ministério do Trabalho e Emprego. Agenda Nacional do Trabalho Decente. Brasília: Ministério do Trabalho e Emprego, 2006, p. 08. Disponível em: http://www.ilo.org/wcmsp5/groups/public/--. americas/---ro-lima/---ilo-brasilia/documents/publication/wcms_226229.pdf. Acesso em: 12 jul. 2018; BRASIL. Ministério do Trabalho e Emprego. Plano Nacional de Trabalho Decente. Brasília: OIT, 2010, p. 13. Disponível em: http://www.ilo.org/wcmsp5/groups/public/---americas/---ro-lima/---ilobrasilia/documents/publication/wcms_226249.pdf. Acesso em: 12 jul. 2018.

99 O Conselho de Administração da OIT que, dentre outras atribuições, é responsável pela eleição do Diretor Geral da OIT, é composto por 28 membros do governo, 14 dos representantes dos empregadores e 14 dos trabalhadores, os quais, apesar de composição díspar, possuem a mesma capacidade de voto. 
ISSN 1981-3694

(DOI): 10.5902/1981369433853

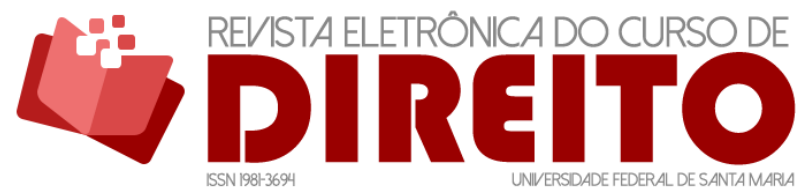

TRABALHO DECENTE SEGUNDO A OIT: UMA CONCEPÇÃO DEMOCRÁTICA? ANÁLISE CRÍTICA À LUZ DA TEORIA DO

CONTRATO SOCIAL

Silvio Beltramelui Neto

ISADORA REZENDE BONAMIM

JULIA DE CARVALHO VOLTANI

necessidade ou convicção), mas em crise estão seus atores ${ }^{100}$. Em outras palavras, representatividade sindical e diálogo social, enquanto ideias, podem servir a processos democráticos de deliberação, mas em outros termos. A respeito, mirando adiante, Boaventura propõe a ampliação democrática dos debates do espaço da produção para a arena social mais ampla e a expansão do rol de atores legitimados para o debate para além do sistema sindical formal brasileiro, que a propósito, também necessita se abrir à democracia participativa.

Seja como for, o diálogo social para a construção da ANTD, segundo os parâmetros aqui adotados, foi evidentemente fraco e insuficientemente democrático.

\section{CONCLUSÃO}

A adoção da concepção de Trabalho Decente - havida sem maiores embates entre as representações do capital e do trabalho, nas instâncias deliberativas da OIT - e seu programa de implementação para o Brasil, a ANTD, não raro são tidas como resultado de um processo democrático, porque pautado pelo tripartismo e pelo diálogo social. Todavia, a teoria do Contrato Social, nos moldes idealizados por Rousseau e aplicada aos limites da OIT e da confecção da ANTD, faz crer que tais processos, sob a ótica dos atores que o protagonizaram, denotam a observância de uma aristocracia eletiva, com a feição atual de democracia representativa.

Esta democracia representativa, no entanto, em termos gerais, encontra-se imersa na crise do Contrato Social, desatada e permanentemente alimentada pela predominância da exclusão social por critérios sobretudo mas não apenas econômicos, situação que, por si, inviabiliza a formação da vontade geral (comunitarista/solidarista por definição) e, por conseguinte, do Soberano, com isso impedindo seja vivenciada, em sua plenitude, uma verdadeira democracia, ainda que na forma representativa. Tal quadro se intensifica nos espaços públicos e privados de representação determinada pelo voto, como a Conferência Internacional da OIT e a administração dos sindicatos brasileiros.

A crise do Contrato Social em escala global, nacional e local, em tempos atuais, agudizada e devota da proeminência do capital neoliberal internacionalizado, afeta a condição eletiva dos representantes dos Estados, dos trabalhadores e dos empregadores, figurantes no diálogo social tripartido levado a efeito nas searas internacional e nacional. Consequentemente,

100 DIAZ, Luiz Eduardo. Democracia y diálogo social. Justicia, Barranquilla, n. 30, p. 132-151, 2016, p. 146 e 148. 
ISSN 1981-3694

(DOI): $10.5902 / 1981369433853$

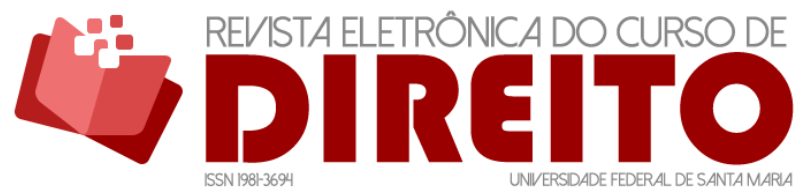

TRABALHO DECENTE SEGUNDO A OIT: UMA CONCEPÇÃO DEMOCRÁTICA? ANÁLISE CRÍTICA À LUZ DA TEORIA DO

CONTRATO SOCIAL

Silvio Beltramelui Neto

ISADORA REZENDE BONAMIM

JULIA DE CARVALHO VOLTANI

como adverte Boaventura de Sousa Santos (apoiado no próprio Rousseau), a prerrogativa do voto, seja para a formação do Governo, seja para a composição da diretiva sindical, não deve ser o quanto basta para classificar de plenamente democráticas as deliberações havidas a propósito do Trabalho Decente. As crises global e brasileira da representatividade sindical, o discurso liberal mundial da despolitização das relações de trabalho, o engessamento formal (normativo) da representação sindical e o diálogo social fraco na modalidade de "consulta" são aspectos que fundamentam a suspeita recaída sobre afirmação peremptória do caráter plenamente democrático da ideia de Trabalho Decente e da elaboração da ANTD brasileira. Mais do que isso, justificam seu tratamento como processos deliberativos não suficientemente democráticos.

Não se trata de negar o valor da democracia representativa para a convivência social minimamente democrática, aí considerada com destaque a agremiação formal de trabalhadores, mas cuida-se de que sejam evitados apriorismos que impeçam problematizações a bem do aperfeiçoamento dos processos deliberativos orientados à legitimidade pela inclusão.

Conquanto complexas, sobretudo quando combativas da exclusão social e propositivas da ampliação dos espaços e dos atores privados frente aos campos públicos de decisão, em prol da verdadeira e única vontade geral, as discussões teóricas e procedimentais acerca da prática da democracia são necessárias e a atuação da OIT para a consecução do Trabalho Decente delas não pode escapar.

\section{REFERÊNCIAS}

ABRAMO, Laís. Trabalho Decente: o itinerário de uma proposta. Bahia Análise \& Dados, Salvador, v. 20, n. 2/3, p. 151-171, jul./set. 2010.

AIETA, Vânia S. Democracia. In: BARRETO, Vicente de P. (Coord.). Dicionário de filosofia do direito. São Leopoldo/Rio de Janeiro: Editora Unisinos; Livraria Editora Renovar, 2009.

ALVES, Giovanni. A disputa pelo intangível: estratégias gerenciais da capital na era da globalização. In: ANTUNES, Ricardo (Org.). Riqueza e miséria do trabalho no Brasil III. São Paulo: Boitempo, 2014.

ANTUNES, Ricardo. Adeus ao trabalho? Ensaio sobre as metamorfoses e a centralidade do mundo do trabalho. 9. ed. São Paulo: Cortez; Campinas: Editora da Unicamp, 2003.

ANTUNES, Ricardo; DRUCK, Graça. A epidemia da terceirização. In: ANTUNES, Ricardo (Org.). Riqueza e miséria do trabalho no Brasil III. São Paulo: Boitempo, 2014. 
ISSN 1981-3694

(DOI): $10.5902 / 1981369433853$

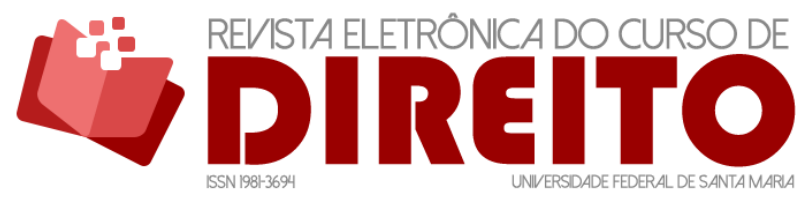

TRABALHO DECENTE SEGUNDO A OIT: UMA CONCEPÇÃO DEMOCRÁTICA? ANÁLISE CRÍTICA À LUZ DA TEORIA DO

CONTRATO SOCIAL

SiLVio Beltramelui Neto ISADORA REZENDE BONAMIM JULIA DE CARVALHO VOLTANI

ANTUNES, Ricardo; SILVA, Jair Batista da. Para onde foram os sindicatos? Do sindicalismo de confronto ao sindicalismo negocial. Caderno CRH, Salvador, v. 28, n. 75, p. 511-527, Dez/2015.

ARGENTINA. MINISTERIO DEL TRABAJO, EMPLEO Y SEGURIDAD SOCIAL. Trabajo decente: significados y alcances del concepto. Indicadores propuestos para su medición. Buenos Aires: Ministerio del Trabajo, Empleo y Seguridad Social, 2005. Disponível em: http://trabajo.gob.ar/downloads/biblioteca_estadisticas/toe03_07trabajo-decente.pdf. Acesso em: 12 jul. 2018.

BARRETTI GHIONE, Hugo. Concepto y dimensiones del trabajo decente. Derecho laboral, tomo XLIV, n. 204, oct./dic. 2001, Montevideo, p. 695-716.

BRASIL. Ministério do Trabalho e Emprego. Agenda Nacional do Trabalho Decente. Brasília: Ministério do Trabalho e Emprego, 2006. Disponível em:

http://www.ilo.org/wcmsp5/groups/public/---americas/---ro-lima/---ilobrasilia/documents/publication/wcms_226229.pdf. Acesso em: 12 jul. 2018.

BRASIL. Ministério do Trabalho e Emprego. Plano Nacional de Trabalho Decente. Brasília: Ministério do Trabalho e Emprego, 2010. Disponível em:

http: / / www.ilo.org/wcmsp5/groups/public/---americas/---ro-lima/---ilobrasilia/documents/publication/wcms_226249.pdf. Acesso em: 12 jul. 2018.

BRASIL. Ministério do Trabalho e Emprego. Portaria MTE n. ${ }^{\circ} 447$, de 19 de agosto de 2004. In: Diário Oficial da União, Brasília, DF, 20 ago. 2004. Disponível em: https: //www.legisweb.com.br/legislacao/?id=188173. Acesso em: 12 jul. 2018.

CENTRAL ÚNICA DOS TRABALHADORES. Terceirização e Desenvolvimento: uma conta que não fecha - Dossiê acerca do impacto da Terceirização sobre os trabalhadores e propostas para garantir a igualdade de direitos. São Paulo: Central Única dos Trabalhadores, 2014. Disponível em: https://www.cut.org.br/system/uploads/ck/files/Dossie-Terceirizacao-e-

Desenvolvimento.pdf. Acesso em: 12 jul. 2018.

DIAZ, Luiz Eduardo. Democracia y diálogo social. Justicia, Barranquilla, n. 30, p. 132-151, 2016.

DIEESE. Nota técnica $n^{\circ}$ 172: terceirização e precarização das condições de trabalho - Condições de trabalho e remuneração em atividades tipicamente terceirizadas e contratantes. São Paulo: DIEESE, 2017. Disponível em:

https://www.dieese.org.br/notatecnica/2017/notaTec172Terceirizacao.html. Acesso em 12 jul. 2018.

DIEESE. Nota Técnica $n^{\circ}$ 175: Impactos da lei 13.429/17 (antigo PL 4.302/1998) para os trabalhadores. São Paulo: DIEESE, 2017. Disponível em:

https://www.dieese.org.br/notatecnica/2017/notaTec175TerceirizacaoTrabalhoTemporario.ht $\underline{\mathrm{ml}}$. Acesso em 12 jul. 2018.

DRUCK, Graça. Terceirização: (des)fordizando a fábrica. Um estudo do complexo petroquímico. Salvador: EDUPA; São Paulo: Boitempo, 2001.

FRANÇA, Carlos Eduardo; CABRAL, Rafael L. Direitos sociais e identidade operária: o poder da ideologia trabalhista no governo de Getúlio Vargas (Brasil, 1930-45). Revista Eletrônica do 
ISSN 1981-3694

(DOI): 10.5902/1981369433853

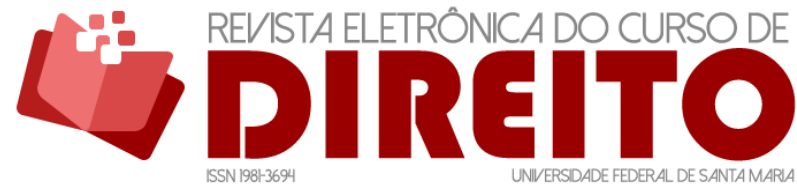

TRABALHO DECENTE SEGUNDO A OIT: UMA CONCEPÇÃO DEMOCRÁTICA? ANÁLISE CRÍTICA À LUZ DA TEORIA DO

CONTRATO SOCIAL

Silvio Beltramelli Neto ISADORA REZENDE BONAMIM JULIA DE CARVALHO VOLTANI

Curso de Direito da UFSM, Santa Maria, RS, v. 13, n. 1, p. 1-19, abr. 2018. ISSN 1981-3694. Disponível em: https://periodicos.ufsm.br/revistadireito/article/view/21961/pdf. Acesso em: 12 jul. 2018. doi: http://dx.doi.org/10.5902/1981369421961.

GALVÃO, Andréia; TEIXEIRA, Marilane O. Flexibilização na lei e na prática: o impacto da reforma trabalhista sobre o movimento sindical In: KREIN, José Dari; GIMENEZ, Denis M.; SANTOS, Anselmo L. (Coord.). Dimensões críticas da reforma trabalhista no Brasil. Campinas/SP: Curt Nimuendajú, 2018.

GHAI, Dharam. Decent work: concept and indicators. International Labour Review, Genebra, v. 142, n. 2, 113-145, 2003.

HARVEY, David. A condição pós-moderna. Trad. Adail Ubirajara Sobral e Maria Stela Gonçalves. 13. ed. São Paulo: Loyola, 2004.

HOBSBAWM, Eric J. Mundos do trabalho. Trad. Waldea Barcellos e Sandra Bedran. 3. Ed. São Paulo: Paz e Terra, 2000.

IBGE. Aspectos das Relações de Trabalho e Sindicalização. IBGE: Rio de Janeiro, 2017.

IBGE. Pesquisa Nacional por Amostra de Domicílios Contínua: outubro a dezembro de 2017. Brasília: IBGE, 2018. Disponível em: <https://goo.gl/6FvmZF>. Acesso em: 30 abr. 2018.

ISHIKAWA, Junko. Aspectos clave del Diálogo Social Nacional: un documento de referencia sobre el Diálogo Social. Ginebra, Oficina Internacional del Trabajo, 2004.

LEVAGGI, Virgilio. Democracia y trabajo decente en América Latina. Lima: OIT, 2006.

MELEU, Marcelino da Silva; BANDEIRA, Laís Cristina. A relação laboral na policontexturalidade voltada a uma gorvernança por números e a OIT como organização mediadora. Revista Eletrônica do Curso de Direito da UFSM, Santa Maria, RS, v. 13, n. 1, p. 183-208, abr. 2018, p. 197. ISSN 1981-3694. Disponível em:

https: //periodicos.ufsm.br/revistadireito/article/view/28239. Acesso em: 12 jul. 2018. doi: http://dx.doi.org/10.5902/1981369428239.

MERINO, Lucyla Tellez. A Eficácia do Conceito de Trabalho Decente nas Relações Trabalhistas. 2011. 216 f. Tese (Doutorado), Universidade de São Paulo, São Paulo, 2011.

MISAILIDIS, Mirta L. Os desafios do sindicalismo brasileiro diante das atuais tendências. São Paulo: LTr, 2001.

OIT. CONFERENCIA INTERNACIONAL DEL TRABAJO. 87ª reúnion. Memoria Del Director General: Trabajo decente. Genebra: Oficina Internacional del Trabajo Ginebra, OIT, 1999. Disponível em: http://www.ilo.org/public/spanish/standards/relm/ilc/ilc87/rep-i.htm. Acesso em: 12 jul. 2018.

OIT. CONFERENCIA INTERNACIONAL DEL TRABAJO. $88^{\mathrm{a}}$ reúnion. Memoria del Director General: Anexo: Informe sobre la situación de los trabajadores en los territorios árabes ocupados. Ginebra: OIT, 2000. Disponível em: 
ISSN 1981-3694

(DOI): 10.5902/1981369433853

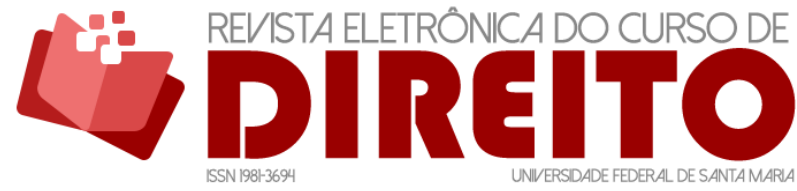

TRABALHO DECENTE SEGUNDO A OIT: UMA CONCEPÇÃO DEMOCRÁTICA? ANÁLISE CRÍTICA À LUZ DA TEORIA DO

CONTRATO SOCIAL

Silvio BeltramelLi Neto ISADORA REZENDE BONAMIM JULIA DE CARVALHO VOLTANI

http://www.ilo.org/public/spanish/standards/relm/ilc/ilc88/rep1a-a.htm. Acesso em: 12 jul. 2018.

OIT. CONFERENCIA INTERNACIONAL DEL TRABAJO. 89a reúnion. Memoria del Director General Reducir el Deficit del Trabajo Decente: un desafío global. Ginebra: OIT, 2001. Disponível em: http://www.ilo.org/public/spanish/standards/relm/ilc/ilc89/pdf/rep-i-a.pdf. Acesso em: 12 jul. 2018.

OIT. CONFERENCIA INTERNACIONAL DEL TRABAJO. 89a reúnion. Discusión del informe del Presidente del Consejo de Administración y de la Memoria del Director General (cont.): OIT, 2001. Disponível em: http://www.ilo.org/public/spanish/standards/relm/ilc/ilc89/pdf/pr5s4.pdf. Acesso em: 12 jul. 2018.

OIT. CONFERENCIA INTERNACIONAL DEL TRABAJO. 89ª reúnion. Actas Provisionales: Respuesta del Director General a la discusión de su Memoria: OIT, 2001. Disponível em:

http://www.ilo.org/public/spanish/standards/relm/ilc/ilc89/pdf/pr-5s4.pdf. Acesso em: 12 jul. 2018.

OIT. Uma década de trabalho decente no Brasil: uma estratégia de ação baseada no diálogo social. Genebra: OIT, 2015. Disponível em: http://www.ilo.org/wcmsp5/groups/public/--americas/---ro-lima/---ilo-brasilia/documents/publication/wcms_467352.pdf. Acesso em: 12 jul. 2018.

ROUSSEAU, Jean-Jaques. Do contrato social. Trad. Pietro Nassetti. São Paulo: Martin Claret, 2004.

ROUSSEAU, Jean-Jaques. Discurso sobre a origem e os fundamentos da desigualdade entre os homens. Trad. Laurent de Saes. São Paulo: Edipro, 2015.

SANTOS, Boaventura de $\mathrm{S}$. The resilience of abyssal exclusions in our societies: toward a postabyssal law. Tilburg Law Review, v. 22, n. 1-2, p. 237-258, 2017.

SANTOS, Boaventura de S. Pela mão de Alice: o social e o político na pós-modernidade. São Paulo: Cortez, 2013.

SANTOS, Boaventura de S. A gramática do tempo: para uma nova cultura política. 2. ed. Porto: Edições Afrontamento, 2010.

SANTOS, Boaventura de S. Do pós-moderno ao pós-colonial. E para além de um e de outro. Travessias, n. 6/7, p. 15-36, 2008.

SANTOS, Boaventura de S.; COSTA, Hermes A. Para ampliar o cânone do internacionalismo operário. In: SANTOS, Boaventura de Sousa (Org.). Trabalhar o mundo: os caminhos do novo internacionalismo operário. Rio de Janeiro: Civilização Brasileira, 2005.

SANTOS, Boaventura de S. Poderá o direito ser emancipatório? Revista Crítica de Ciências Sociais, n. 65, p. 03-76, 2003.

SANTOS, Boaventura de S. A crítica da razão indolente: contra o desperdício da experiência. 2 . ed. Porto: Edições Afrontamento, 2002. 
ISSN 1981-3694

(DOI): $10.5902 / 1981369433853$

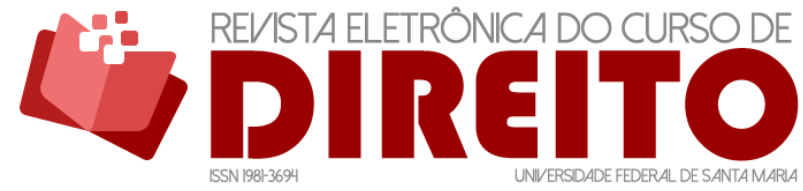

TRABALHO DECENTE SEGUNDO A OIT: UMA CONCEPÇÃO DEMOCRÁTICA? ANÁLISE CRÍTICA À LUZ DA TEORIA DO

CONTRATO SOCIAL

Silvio Beltramelli Neto ISADORA REZENDE BONAMIM JULIA DE CARVALHO VOLTANI

SEHNBRUCH, Kirsten; BURCHEL, Brendan; AGLONI, Nurjk; PIASNA, Agnieska. Human development and decent work: why some concepts succeed and others fail to make an impact. Development and Change, v. 46, n. 2, p. 197-224, 2015.

SEN, Amartya; NUSSBAUM, Martha. C. Alocución del Sr. Amartya Sen, Premio Nobel de Economía. 87ª . Conferencia Internacional del Trabajo, 1999.

SEN, Amartya. Desenvolvimento como liberdade. Trad. Laura Teixeira Mota. São Paulo: Companhia das Letras, 2010.

TREBILCOCK, Anne. Towards social dialogue: Tripartite cooperation in national economic and social policy-making. Ginebra: OIT, 1994.

URIARTE, Oscar Ermida. Diálogo social: teoría y práctica. Sindicatos y diálogo social: situación actual y perspectivas, v. 3, n. 120, p. 57, 2000.

VOSKO, LeahF. 'Decent Work' The Shifting Role of the ILO and the Struggle for Global Social Justice. Global Social Policy Canada, v. 2, p.19-46, 2002.

YOUNG, Iris Marion. Representação política, identidade e minorias. Lua Nova, São Paulo, n. 67, p.139190, 2006.

Recebido em: 22.07.2018 / Aprovado em: 15.04.2019 / Publicado em: 06.05.2019

\section{COMO FAZER REFERÊNCIA AO ARTIGO (ABNT):}

BELTRAMELLI NETO, Silvio; BONAMIM, Isadora Rezende; VOLTANI, Julia De Carvalho Trabalho decente segundo a OIT: uma concepção democrática? Análise crítica à luz da teoria do contrato social. Revista Eletrônica do Curso de Direito da UFSM, Santa Maria, RS, v. 14, n. 1, e33853, jan./abr. 2019. ISSN 1981-3694. DOI: http: //dx.doi.org/10.5902/1981369433853. Disponível em: https://periodicos.ufsm.br/revistadireito/article/view/33853 Acesso em: dia mês. ano.

Direitos autorais 2019 Revista Eletrônica do Curso de Direito da UFSM

Editores responsáveis: Rafael Santos de Oliveira e Angela Araujo da Silveira Espindola

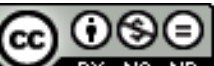

Este obra está licenciado com uma Licença Creative Commons Atribuição-NãoComercial-SemDerivações 4.0 Internacional.

\section{SOBRE OS AUTORES}

SILVIO BELTRAMELLI NETO

Professor Titular Categoria A1 da PUC-Campinas, vinculado ao Programa de Pós-Graduação em Direito, linha de pesquisa "Cooperação Internacional e Direitos Humanos", grupo de pesquisa Direito num Mundo Globalizado (CNPQ/PUC-Campinas). Pós-doutorando em Desenvolvimento Econômico pelo Instituto de Economia da Universidade Estadual de Campinas UNICAMP, integrando o Centro de Estudos Sindicais e de Economia do Trabalho - CESIT. Doutor em Direito (2013) pela Universidade de São Paulo - USP. Mestre (2007) em Direito pela Universidade Metodista de Piracicaba - UNIMEP. Especialista (2001) em Direito e Processo do Trabalho pela PUC-Campinas (2001). Graduado pela PUC-Campinas em 1999. Membro do Ministério Público do Trabalho (Procurador do Trabalho). Dedica-se, precipuamente, à investigação das relações de trabalho 
ISSN 1981-3694

(DOI): $10.5902 / 1981369433853$

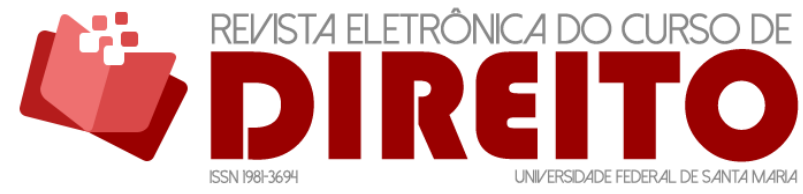

TRABALHO DECENTE SEGUNDO A OIT: UMA CONCEPÇÃO DEMOCRÁTICA? ANÁLISE CRÍTICA À LUZ DA TEORIA DO

sob a ótica dos direitos humanos, desenvolvendo, atualmente, plano de pesquisa intitulado "O marco teórico da concepção de Trabalho Decente da OIT: as relações laborais na perspectiva do desenvolvimento social segundo Amartya Sen". Na graduação da Faculdade de Direito da PUC-Campinas, ministra as disciplinas "Direitos Humanos", "Estágio Supervisionado em Prática de Direitos Humanos", "Direito do Trabalho Aplicado" e "Metodologia Jurídica". Autor de artigos científicos e dos livros "Limites da Flexibilização dos Direitos Trabalhistas" (Ed. LTR, 2008), "Direito fundamental à moradia do trabalhador migrante" (Ed. Leopoldianum, 2015) e "Direitos Humanos" (Ed. Juspodivm, 5. ed., 2018). Integrante de conselhos editoriais e parecerista "ad hoc" de revistas científicas.Editor-Chefe da Revista Jurídica Trabalho e Desenvolvimento Humano - Revista Jurídica da Procuradoria do Trabalho da $15^{\text {a }}$ Região (ISSN 2595-9689).

\section{ISADORA REZENDE BONAMIM}

Acadêmica de Direito na Pontifícia Universidade Católica de Campinas (PUC-Campinas). Integra o Grupo de Estudos Ciências Criminais e Direitos Humanos do Instituto Brasileiro de Ciências Criminais (IBCCRIM). É pesquisadora no Grupo de Estudos de Arbitragem Comercial (GEAC) da PUC-Campinas. Voluntária na ONG "Voto Consciente-Jundiaí" na área de Educação. Foi aluna pesquisadora de Iniciação Científica com bolsa provida pela FAPESP para desenvolver o plano de pesquisa sob o título "Conteúdo e Estágio de Implementação dos Programas Brasileiros de Trabalho Decente". Atuou como monitora bolsista na disciplina de Direito Penal, também pela Pontifícia Universidade Católica de Campinas, tendo exercido a mesma atividade durante o Ensino Médio, na Organização Educacional Farias Brito (Fortaleza/CE), nas disciplinas de Biologia e Inglês (2013). Recebeu bolsa da PUC-Campinas para aperfeiçoamento do idioma espanhol na escola Fundación de la Lengua Espanõla, em Valladolid/ES. Realizou estágio na Procuradoria Geral da Fazenda Nacional (2016) e na Fundação Professor Dr. Manoel Pedro Pimentel (2017).

\section{JULIA DE CARVALHO VOLTANI}

Graduanda do curso de Direito pela Pontifícia Universidade Católica de Campinas. Bolsista de Iniciação Científica pelo Fundação de Amparo à Pesquisa do Estado de São Paulo (FAPESP), atualmente desenvolve pesquisa sob a temática "Investigação histórica da construção da concepção de Trabalho Decente adotada pela OIT", com linha de pesquisa: Cooperação jurídica internacional, sob orientação do Professor Dr. Silvio Beltramelli Neto.Realizou estágio no Juizado Especial Cilvel - PAC- Puc- Campinas (2016) e na Assistência Judiciária " DR CARLOS FOOT GUIMARÃES". 